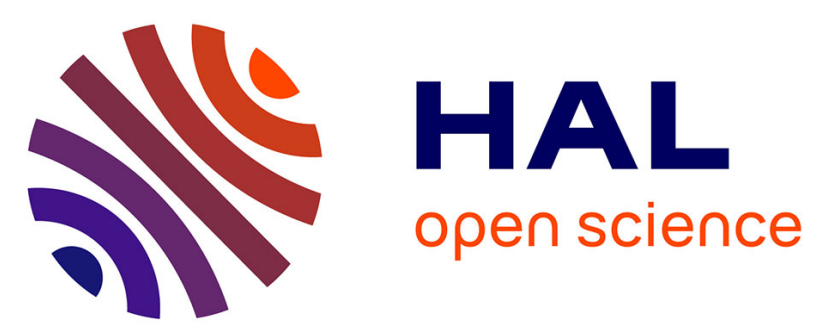

\title{
The Genitive Case and the Possessive Construction in Finnish
}

\author{
Marc-Antoine Mahieu
}

\section{To cite this version:}

Marc-Antoine Mahieu. The Genitive Case and the Possessive Construction in Finnish. Anne Carlier \& Jean-Christophe Verstraete. The Genitive, John Benjamins, pp.19-54, 2013, Case and Grammatical Relations Across Languages 05, 10.1075/cagral.5.04mah . hal-01411331

\section{HAL Id: hal-01411331 \\ https://hal-inalco.archives-ouvertes.fr/hal-01411331}

Submitted on 7 Dec 2016

HAL is a multi-disciplinary open access archive for the deposit and dissemination of scientific research documents, whether they are published or not. The documents may come from teaching and research institutions in France or abroad, or from public or private research centers.
L'archive ouverte pluridisciplinaire HAL, est destinée au dépôt et à la diffusion de documents scientifiques de niveau recherche, publiés ou non, émanant des établissements d'enseignement et de recherche français ou étrangers, des laboratoires publics ou privés.

\section{(ㅇ)(1) $\$$}

Distributed under a Creative Commons Attribution - NonCommercial - NoDerivatives| 4.0 


\section{The Genitive Case and the Possessive Construction in Finnish}

Marc-Antoine Mahieu

\section{Introduction ${ }^{1}$}

Finnish is the most widely spoken of the languages comprising the Finnic branch of the Uralic family. It has some five million speakers, most of them in Finland. The complexity of its case system has been remarked upon since the $17^{\text {th }}$ century (Korhonen 1987:92-100); the modern grammatical tradition identifies fifteen different case morphemes in all. Table 1 shows Setälä's (1898:47-52) analysis of this system. This work is a school grammar which remained the model for codification up to the 1950s. ${ }^{2}$ Nowadays, the partitive is usually grouped with the nominative, the accusative, and the genitive on the grounds that these four morphemes share the property of being able to affect the subject and/or the direct object. ${ }^{3}$

Table 1 : The traditional analysis of the Finnish case system

\begin{tabular}{|c|c|c|c|}
\hline \multirow[t]{3}{*}{$\begin{array}{l}\text { GRAMMATICAL } \\
\text { CASES }\end{array}$} & nominative & $\varnothing$ & $\begin{array}{l}\text { basic form } \\
\text { (nimentö) }\end{array}$ \\
\hline & accusative & $\begin{array}{ll}0 . & -\boldsymbol{t} \\
\text { 1. } & -\boldsymbol{n} \\
\text { 2. } & \varnothing\end{array}$ & $\begin{array}{l}\text { object form } \\
\text { (kohdanto) }\end{array}$ \\
\hline & genitive & $-n$ & $\begin{array}{l}\text { possession } \\
\text { (omanto) }\end{array}$ \\
\hline \multirow{3}{*}{$\begin{array}{l}\text { GENERAL } \\
\text { LOCATIVE } \\
\text { CASES }\end{array}$} & essive & $-n a \sim-n \ddot{a}$ & $\begin{array}{l}\text { state } \\
\text { (olento) }\end{array}$ \\
\hline & partitive & $-(\boldsymbol{t}) \boldsymbol{a} \sim-(\boldsymbol{t}) \ddot{\boldsymbol{a}}$ & $\begin{array}{l}\text { indefinite quantity } \\
\text { (osanto) }\end{array}$ \\
\hline & translative & $-k s i$ & $\begin{array}{l}\text { change of state } \\
\text { (tulento) }\end{array}$ \\
\hline
\end{tabular}




\begin{tabular}{|c|c|c|c|}
\hline \multirow{3}{*}{$\begin{array}{l}\text { INTERNAL } \\
\text { LOCATIVE } \\
\text { CASES }\end{array}$} & inessive & $-s s a \sim-s s \ddot{a}$ & $\begin{array}{l}\text { 'inside' } \\
\text { (sisäolento) }\end{array}$ \\
\hline & elative & $-s t a \sim-s t \ddot{a}$ & $\begin{array}{l}\text { 'out of' } \\
\text { (sisäeronto) }\end{array}$ \\
\hline & illative & $-(h) V n,-s V V n$ & $\begin{array}{l}\text { ‘into’ } \\
\text { (sisätulento) }\end{array}$ \\
\hline \multirow{3}{*}{$\begin{array}{l}\text { EXTERNAL } \\
\text { LOCATIVE } \\
\text { CASES }\end{array}$} & adessive & $-l l a \sim-l l \ddot{a}$ & $\begin{array}{l}\text { 'on', 'at' } \\
\text { (ulko-olento) }\end{array}$ \\
\hline & ablative & $-l t a \sim-l t \ddot{a}$ & $\begin{array}{l}\text { 'off' } \\
\text { (ulkoeronto) }\end{array}$ \\
\hline & allative & $-l l e$ & $\begin{array}{l}\text { 'onto' } \\
\text { (ulkotulento) }\end{array}$ \\
\hline \multirow[t]{3}{*}{$\begin{array}{l}\text { MARGINAL } \\
\text { CASES }\end{array}$} & abessive & $-t t a \sim-t t \ddot{a}$ & $\begin{array}{l}\text { 'without' } \\
\text { (vajanto) }\end{array}$ \\
\hline & comitative & -ine & $\begin{array}{l}\text { 'with' } \\
\text { (seuranto) }\end{array}$ \\
\hline & instructive & $-n$ & $\begin{array}{l}\text { 'by means of' } \\
\text { (keinonto) }\end{array}$ \\
\hline
\end{tabular}

At first glance, the Finnish genitive seems to be just what a "genitive" is usually assumed to be. As suggested by the word omanto, which is sometimes used to designate this case in Finnish, it is ostensibly the case that expresses possession. Examples like (1a) or (1b) can be adduced as evidence. At the same time, though, in this language without a verb 'have', the possessive construction uses the adessive and not the genitive. This construction, illustrated by (1c), is generally analyzed as an existential sentence where the adessive has its characteristic locative sense. In this analysis, the literal meaning of (1c) is 'at Pekka is a car'.
(1) a. Peka-n auto ${ }^{4}$
Pekka-GEN car.NOM
'Pekka's car' 
b. Auto on Peka-n.

car.NOM be.3sg Pekka-GEN

'The car is Pekka's.'

c. Peka-lla on auto.

Pekka-ADE be.3sG car.NOM

'Pekka has a car.'

This paper will argue against all of the viewpoints expressed thus far. First of all, the broad distribution of the Finnish genitive implies that it cannot be reduced to the "case expressing possession". This is true even in the loose sense assigned to "possession" by linguists, i.e. "inclusion of an entity (usually called the thing possessed) within the personal sphere of an individual [or of some cognitively more salient/individuated entity] (usually called the possessor)" (Creissels 2006:143-144). It will be argued here that the Finnish genitive is in fact a structural case, i.e. the simple manifestation of relationships of syntactic dependency.

Secondly, uses of type (1b) should not be conflated with those of type (1c). In a few more or less fossilized constructions, (1b) among them, the case marked by $-n$ is not a true genitive but rather in all probability a vestige of what this case once was, before it became grammaticalized as a genitive morpheme. It will be argued here that $-n$ is a semantic case in such uses, rightly called datiivigenetiivi ('dative-genitive') in traditional grammar, i.e. the manifestation of a P-category head (or adposition).

Thirdly, contrary to what an analysis based solely on noun and verb morphology would suggest, it can be shown that the Finnish possessive construction cannot be treated as an existential sentence, i.e. an utterance composed of an initial locative phrase, a verb 'be', and a postposed subject. A set of convergent arguments can be used to show, firstly, that the postverbal constituent behaves like a direct object of a 'have'-like head and then, that the initial constituent is not an adpositional phrase but rather a 
nominal subject, where the adessive becomes something other than a semantic case.

This paper is organized as follows: in part 2, the structural nature of the Finnish genitive case is demonstrated, and the range of syntactic configurations in which this case can be found is set out. From a typological perspective, the most interesting phenomenon here is without doubt the object genitive and the way it contrasts with other cases. Part 3 discusses the constructions where the morpheme $-n$, though still called genitive, is not a structural case but rather a semantic one with a dative sense. The analysis will include a brief discussion of the origin of the genitive and its cognates in other Uralic languages. Part 4 is devoted entirely to the possessive construction. It will be pointed out that the apparent conclusions drawn from morphology, namely, that this construction is a locative inversion, cannot be reconciled with what can be learned about its structure from a certain number of systematic syntactic manipulations. A transformational analysis is proposed which eliminates the apparent contradiction in the data from a synchronic perspective.

\section{The genitive as a structural case}

This section will show that the Finnish genitive is not definable as the case expressing possession, and more broadly speaking, is not a case expressing any semantic operation at all (in this regard, see Jaakola 2004), but rather a structural case. This means that it is merely the surface reflex of a relationship of syntactic dependency, i.e. it is not itself a syntactic category (adpositional head) with a set of semantic properties.

More precisely, I will argue here that the Finnish genitive reflects not just one but a number of different dependency relationships, since it appears in a range of syntactic configurations which cannot be reduced to each other. 
This means that Vainikka's (1989:126-183; 1993:132-140) theory according to which the Finnish genitive can invariably be analyzed as "the structural default case for the specifier position of each of the lexical categories $\mathrm{N}, \mathrm{A}$, $\mathrm{P}$ and $\mathrm{V}$ " must be rejected.

\subsection{Preposed NP modifier of a $N$ head}

To begin with, the genitive can express a relationship of modification of a nominal head by a preceding NP. This relationship is often assumed to express "possessivization of the noun" on the basis of examples like (1a). It is obvious, however, that an NP in the genitive can take on any one of the many other admissible semantic roles with respect to the nominal head it modifies, e.g. Agent in (2a), Patient in (2b), Theme in (2c), Experiencer in $(2 \mathrm{~d})$, Beneficiary in $(2 \mathrm{e})$, Location in $(2 \mathrm{f})$, Source in $(2 \mathrm{~g})$, or Destination in $(2 \mathrm{~h})$.

(2) a. Peka-n lähto

Pekka-GEN departure.NOM

'Pekka's departure'

b. puu-n tuonti

tree-GEN import.NOM

'the import of wood'

c. musiiki-n opettaja

music-GEN teacher.NOM

'a music teacher'

d. lapse-n suru

child-GEN sorrow.NOM

'a child's sorrow' 


e. voittaja-n palkinto
winner-GEN prize.NOM
'the winner's prize'
f. Vietnami-n sota
Vietnam-GEN war.NOM
'the Vietnam War'
g. Lapi-n mies
Lapland-GEN man.NOM
'a man from Lapland'
h. Pariisi-n juna
Paris-GEN train.NOM
'the train to Paris'

It is also obvious that the role expressed by an NP in the genitive may be ambiguous out of context or hard to define. In (3a), the genitive NP could be either Patient or Agent; in (3b), either Experiencer or Source; and in (3c), either Theme or Agent or Possessor. In (4), although the NP has only one possible role, it is not one of major roles exemplified in (2).

(3) a. Peka-n haastattelu

Pekka-GEN interview.NOM

'the interview Pekka gave, the interview Pekka conducted'

b. sude-n pelko

wolf-GEN fear.NOM

'the fear felt by the wolf, the fear caused by the wolf'

c. ystävä-n kuva

friend-GEN picture.NOM

'a picture made of a friend, a picture drawn by a friend, a picture owned by a friend' 


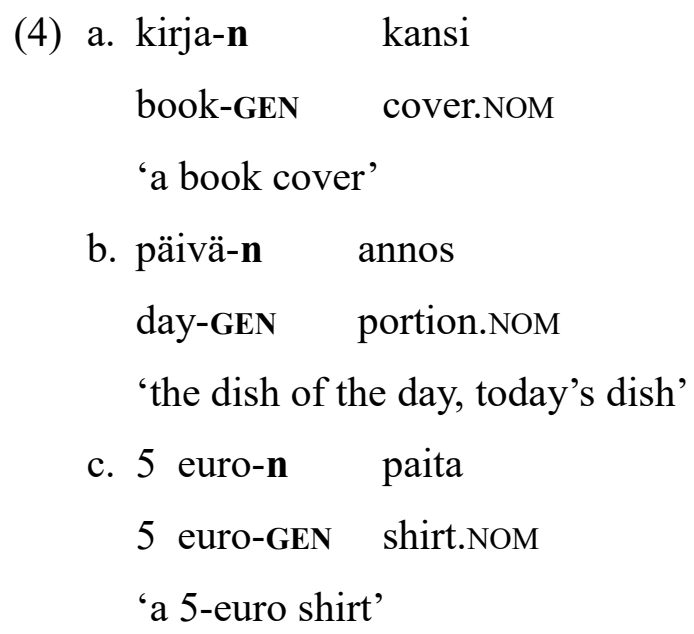

Given these facts, it can be said that the relationship holding between a genitive NP and the nominal head it modifies is totally unspecified. The only requirement is that the genitive noun phrase restricts the set of possible referents for the head noun to those which may stand in a given relationship to itself, whatever that relationship may be. It is not only impossible to give an a priori definition of the semantic role between the genitive NP and the head noun, it is also impossible to say that the genitive NP will invariably take on any given role. Thus, for instance, there are structures like (5), where the NP does no more than identify the entity referred to, in this case by giving its name.
(5) a. Savonlinna-n kaupunki
Savonlinna-GEN city.NOM
'the city of Savonlinna'
b. ranska-n kieli
French-GEN language.NOM
'the French language'
c. Virtase-n perhe
Virtanen-GEN family.NOM
'the Virtanen family' 
d. Virtase-n Pekka

Virtanen-GEN Pekka.NOM

'Pekka Virtanen' (colloquial)

Of course, it may still be assumed that the genitive case has a semantic value insofar as it restricts the possible referents of the head N. This is not the position that will be defended here. Instead, I will argue that the semantic operation of restriction is a function, not of the genitive marking of the premodifier, but rather of the syntactic relationship of premodification itself, which is defined within a given structural configuration. In other words, the source of the restriction is not the genitive case; the genitive is merely the surface reflex of the dependency relationship that assigns a restrictive function to any preposed NP.

There is at least one good argument in favor of this assumption, viz. the fact that the dependency relationship and its associated semantic function persist, even when genitive case is not allowed on the restricting NP. This happens when the restricting NP has a possessive suffix, as in the Finnish example (6). This has become the regular situation in Livonian, another Finnic language where the genitive case has practically disappeared.

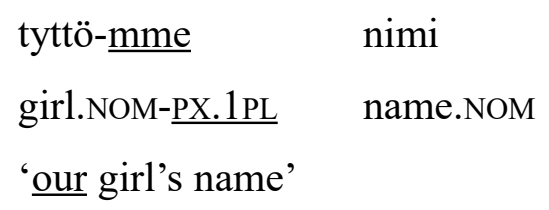

It now remains to be determined exactly what the structural configuration is for the definition of the dependency relationship reflected by the prenominal genitive. According to Vainikka (1993:132-133), the prenominal genitive is the case of the nominal specifier. Nelson (1998:216-217) takes a similar position. This approach ignores important data, however. First of all, the position of the restrictive NP varies with respect to adjectives. When an 
NP refers to a clearly individuated entity, and takes on a concrete and easily defined semantic role, it precedes the adjective. When, on the other hand, its referent is less individuated, and it has an abstract or less easily defined semantic role, it follows the adjective. This contrast is illustrated in (7).

(7)
a. fyysiko-n
uusi
tutkimuslaitos
physicist-GE
new.NOM
research.institute.NOM
'the physicist's new research institute'
b. uusi
fysiika-n
tutkimuslaitos
new.NOM physics-GEN
research.institute.NOM
'the new physics research institute'

In addition, the head noun is sometimes preceded by two restrictive NPs. This is illustrated by the examples in (8), taken from Vilkuna (2000:189193). In ( $8 b$ ), the head of the second restrictive NP (ranskan kielen) is itself modified by an NP in the genitive case. In (8c), the two restrictive NPs are separated by the adjective uudet.

(8)
a. EU:n
viime
vuos-i-en
toime-t
EU-GEN
last
year-PL-GEN
activity-PL.NOM

'the last years' activities of the EU, the activities of the EU over the last few years'

b. Ritu-n

ranska-n

kiele-n

taito

Ritu-GEN French-GEN

language-GEN

skill.NOM

'Ritu's skills in French'

c. Valio-n uude-t

litra-n

purki-t

Valio-GEN new-PL.NOM

litre-GEN

can-PL.NOM

'Valio's new one-litre cans'

This implies that the modification relationship reflected by the 
prenominal genitive needs to be defined in two different structural positions. The restrictive NP may be located either within the head noun's determinative domain, as what Vilkuna (ibid.) would call an "external genitive", or just after the head noun's descriptive domain, as what Vilkuna calls an "internal genitive" (ulkoinen sisäinen genetiivi).

Given these facts, it can be assumed that the first position is that of the specifier of a D head (which selects the maximal projection of $\mathrm{N}$ ) and the second, that of the specifier of the head N. The descriptive domain of $\mathrm{N}$ itself consists of any adjectives that may be adjoined to the maximal projection of $\mathrm{N}$. This dual configuration for the assignment of the prenominal genitive is represented in (9). ${ }^{5}$

$$
[\text { DP NP-GEN [D, D ... [NP NP-GEN [N, N ] ] ] }
$$

\subsection{Preposed AP modifier of an A or Adv head}

The second dependency relationship expressed by the genitive in Finnish is the modification of an A or Adv head by a preceding AP phrase. Thus, the adjective kamala, in the nominative in (10a), takes the genitive in (10b) where it modifies another adjective. The same adjective cannot modify the VP in (10c); the deadjectival adverb, formed with the suffix -sti, is required instead. Example (10d) illustrates the case where the adjective in the genitive premodifies an Adv rather than an A head.

$$
\begin{aligned}
& \text { (10)a. Ilma ol-i kamala. } \\
& \text { weather.NOM be-PRET.3SG terrible.NOM } \\
& \text { 'The weather was terrible.' }
\end{aligned}
$$


b. Ilma ol-i kamala-n kylmä. weather.NOM be-PRET.3SG terrible-GEN cold.NOM 'The weather was terribly cold.'

c. Minu-a palel-i kamalasti. I-PART feel.cold-PRET.3SG terribly

'I was terribly cold.'

d. Eilen tuul-i kamala-n kylmästi. yesterday blow-PRET.3SG terrible-GEN coldly 'The wind was terribly cold yesterday.'

It must be stressed that not all classes of adjectives are allowed in the dependency relationship described here. The adjectives used in these constructions are mainly those that express the intensity of the property denoted by the $\mathrm{A}(\mathrm{dv})$ head as in (11), or an evaluation of that property as in (12).

(11)a. suhteellise-n kallis relative-GEN expensive.NOM 'relatively expensive'

b. riittävä-n luotettava sufficient-GEN reliable.NOM 'sufficiently reliable'

c. äärettömä-n yksinkertainen infinite-GEN simple.NOM 'infinitely simple'

d. erityise-n tarkeä particular-GEN important.NOM 'particularly important' 


$$
\begin{aligned}
& \text { (12)a. yllättävä-n suosittu } \\
& \text { surprising-GEN popular.NOM } \\
& \text { 'surprisingly popular' } \\
& \text { b. harvinaise-n onnistunut } \\
& \text { rare-GEN successful.NOM } \\
& \text { 'uncommonly successful' } \\
& \text { c. turha-n kyyninen } \\
& \text { needless-GEN cynical.NOM } \\
& \text { 'needlessly cynical' } \\
& \text { d. miellyttävä-n tehokas } \\
& \text { pleasant-GEN efficient.NOM } \\
& \text { 'pleasantly efficient' } \\
& \text { e. sairaa-n huolestunut } \\
& \text { ill-GEN worried.NOM } \\
& \text { 'pathologically worried' (colloquial) }
\end{aligned}
$$

Adjectives that are not generally allowed to modify another adjective or an adverb include both epistemic and thematic adjectives. In such cases an adverb is required: selvästi iloinen 'clearly happy', historiallisesti epätarkka 'historically inaccurate'. Still, exceptions nevertheless exist, like ilmeisen väärä 'patently false'. Yet the validity of the main assertion is never in doubt: when an A or Adv head is modified by an adjective, the latter takes the genitive case. Furthermore, in this case, we may follow Vainikka (1993:131-133) and assume that the AP does so by virtue of being a specifier of the head it modifies:

$$
\text { [A(dv)P AP-GEN [A(dv)' A(dv)]] }
$$

Two further remarks are required: firstly, there is one very particular set of expressions that can take the genitive in the same syntactic position as the 
AP in (13), namely swearwords. These are categorially nouns, or they come from nouns. It is otherwise extremely rare for an A or Adv head to be modifiable by an NP in the genitive. ${ }^{6}$

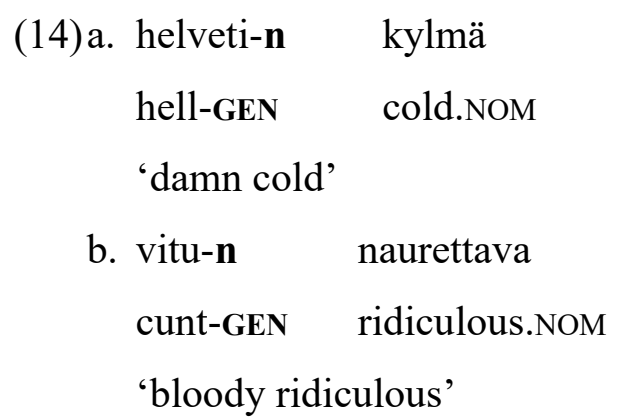

Next, the set of items represented by the Adv head in (13) includes the words paljon and vähän, which are both quantifying adverbs ('much' and 'little') and quantifying determiners ('a lot of' and 'a bit of'). ${ }^{7}$ Marginally, we can also find instances of quantifying pronouns/determiners like moni 'much' being modified by an AP in the genitive.

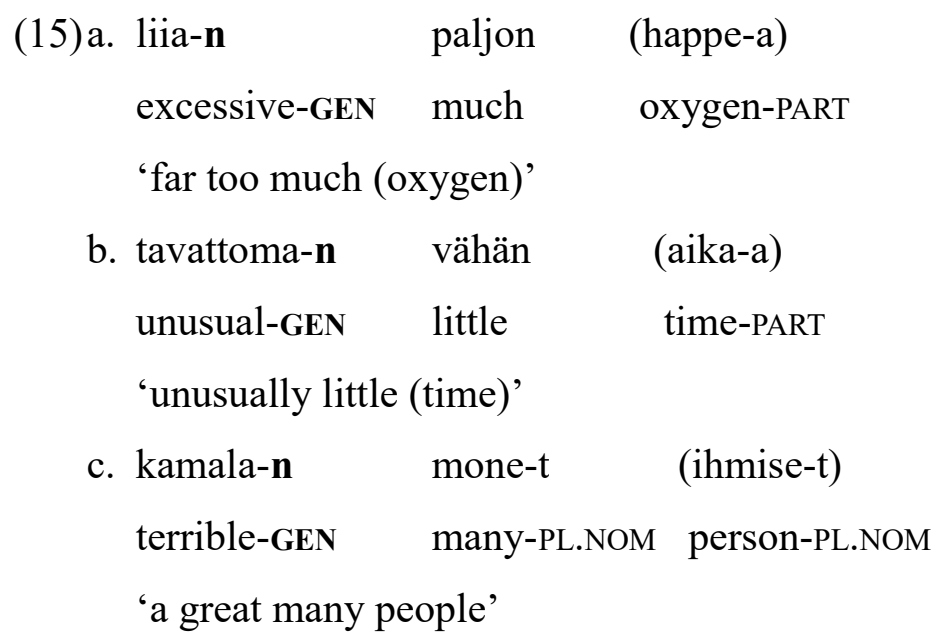




\subsection{Preposed NP or AP complement to an A head}

A third dependency relationship expressed by the Finnish genitive is the complementization of an A head by a preceding NP or AP. The adjectives involved are all formed with the -inen suffix and express a measurable objective property (16), a sensory perception or general impression (17), or a spatiotemporal relationship (18). The adjectives in this last group are complementized only by NPs. (See Hakulinen et al. 2004:604-606.)

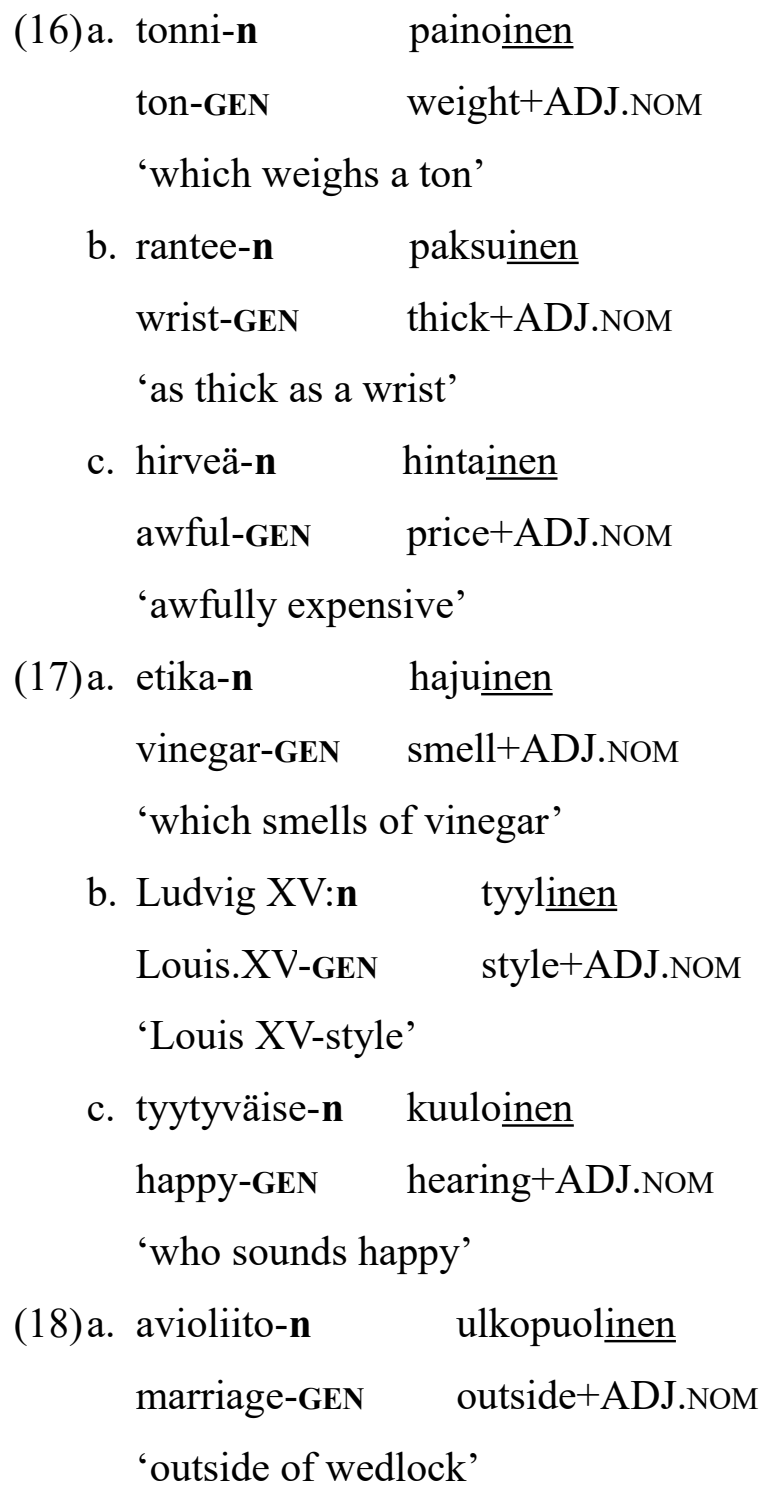


b. jääkaude-n jälkeinen

Ice.Age-GEN after+ADJ.NOM

'subsequent to the Ice Age'

Note that the complements of adjectives in the comparative (-mpi) take the partitive and not the genitive. One thus finds Pekkaa pitempi 'bigger than Pekka' but Pekan pituinen 'of Pekka's size'. Alternatively, the comparative complement can be postposed and introduced in the nominative by the complementizer kuin (pitempi kuin Pekka). Note further that some adjectives with a genitive complement can be made into -sti adverbs, e.g. sen mukaisesti 'in accordance with that'.

It now remains to be determined what syntactic configuration results in the assignment of genitive case to the adjective complement. In the analysis of Vainikka (1993:134) the situation described in 2.2 would be assimilated to the present one, and the genitive case would be assigned to the NP or AP complement as specifier of A. This position appears untenable, however. First of all, we are dealing with a true complement subcategorized by the A head rather than just a modifier. It might therefore be expected to stand in a different position. Furthermore, the specifier position is sometimes independently filled, as in vähän isän näkoinen 'somewhat like Dad' or täsmälleen saman kokoinen 'of exactly the same size'. It must therefore be concluded that the complement of A occupies the sister-of-A position: ${ }^{8}$

$$
\left[\text { AP ... }\left[{ }^{A}, \mathrm{NP} / \mathrm{AP}-\mathrm{GEN} \mathrm{A}\right]\right]
$$

\subsection{Preposed NP complement to a P head}

The genitive also expresses the complementization relationship between a $\mathrm{P}$ head and a preposed NP. In other words, it is the case governed by 
postpositions, at least in the "default" situation. By way of comparison, the case governed by prepositions, which are far less numerous in Finnish, is the partitive. Some adpositions can take a preposed NP complement in the genitive or a postposed NP in the partitive, sometimes with a change in meaning, as illustrated in (20).

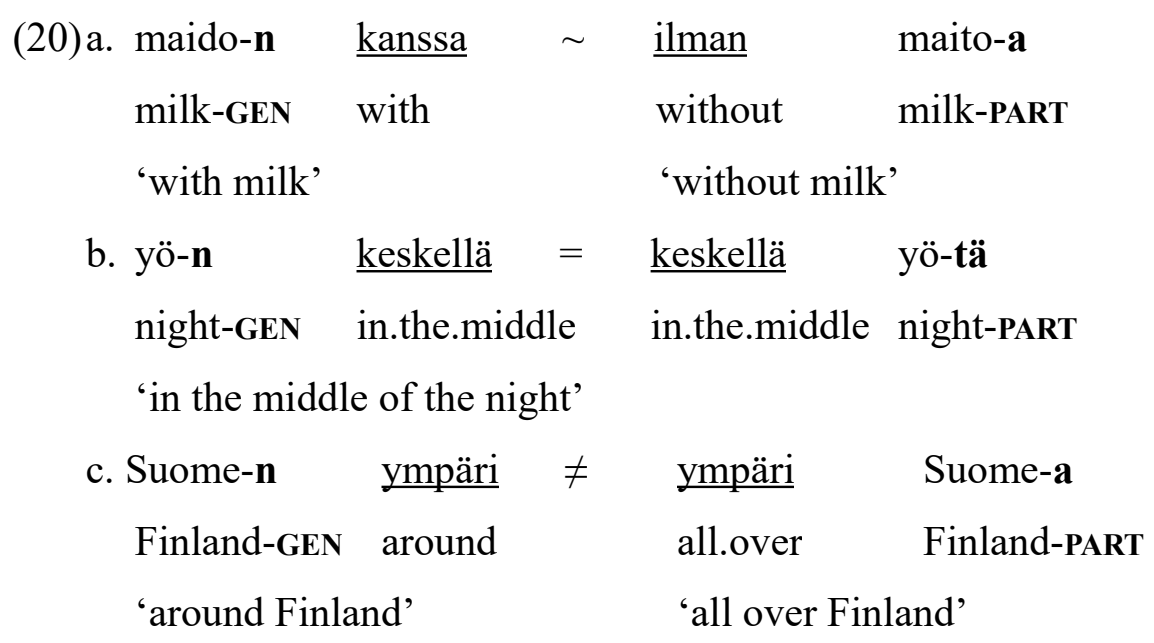

There are a number of facts which complicate this picture. (1) A few postpositions can be shifted to a position before their genitive complement, sometimes with a change in meaning. (2) Several postpositions govern the partitive rather than the genitive. (3) To a greater or lesser extent, prepositions can be shifted to a position following their partitive complement. (4) Many adpositions deriving from the reanalysis of a participle govern a locative case (illative, elative, ablative). An ordered illustration of each of these points is provided in (21) to (24). Exhaustive lists and additional data can be found in Hakulinen et al. (2004:674-700).

$\begin{array}{llll}\text { (21)a. kaupungi-n läpi } & = & \underline{\text { läpi }} & \text { kaupungi-n } \\ \text { town-GEN through } & \text { through } & \text { town-GEN } \\ \text { 'through the town' } & & \end{array}$




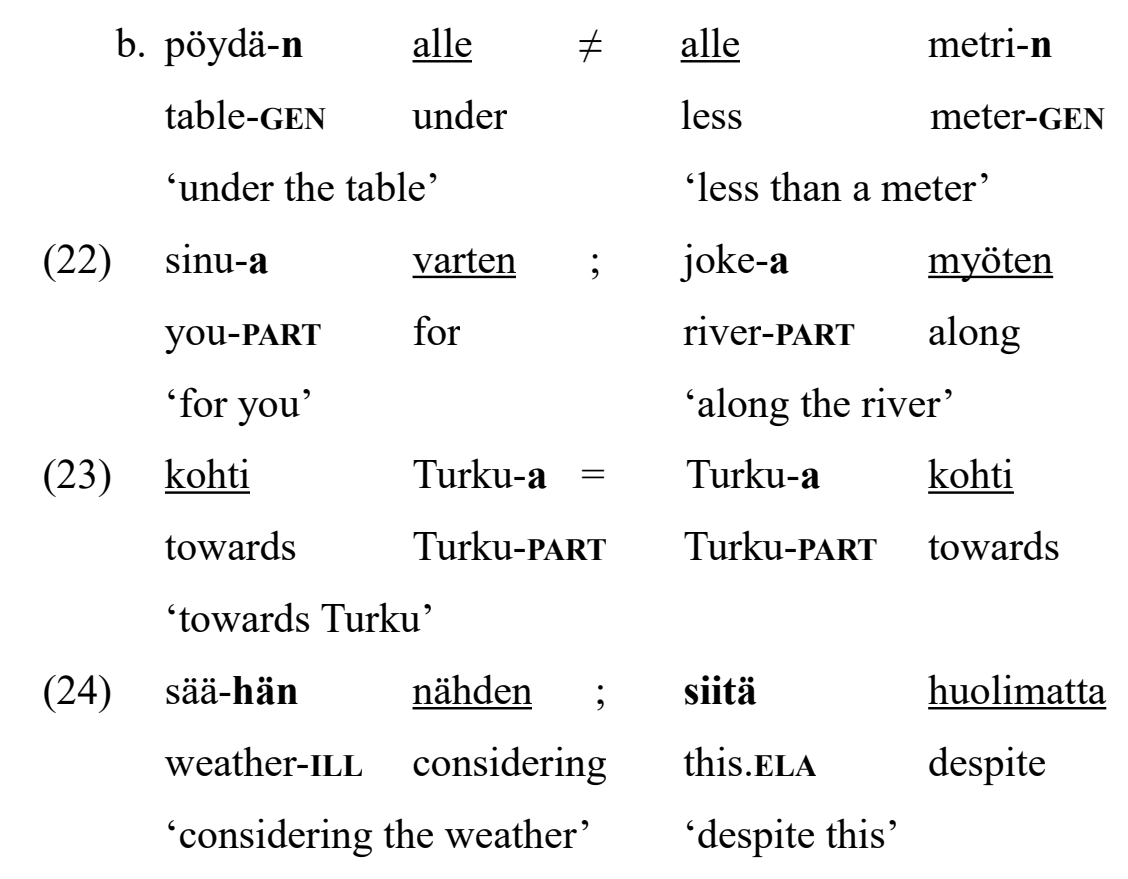

It is not straightforward to determine the syntactic position in which the genitive is assigned to the complement of postpositions. According to Vainikka (1993:135-137), the position is that of specifier of a P head. The partitive in turn should be assigned to the sister-of-P position. There are indeed several arguments which support this point. One is that most postpositions were originally nouns in a locative case with the genitive NP as premodifier (see $\S 2.1$ ). Sometimes this is evident (edessä 'in front of' $<$ ete- + -ssA), sometimes less so (kanssa 'with' < kansa + -ssA 'in company of'). Furthermore, the constraints on the complement of a P head vary according to whether it is preposed or postposed. For example, a preposed NP cannot contain a postmodifier: pullon (*vettä) sisällä 'in the (water) bottle'.

In spite of this, it is hard to maintain that postpositions assign the genitive to their specifier, not just because of examples like (21), but also because the specifier position can perfectly well be independently filled: (lähes) kuvan

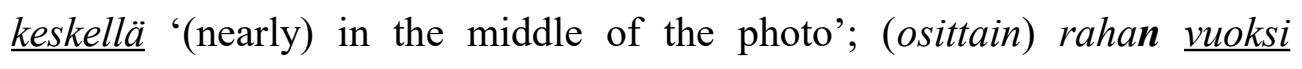
'(partly) for money'; (vähän) Pekan takana '(a little) behind Pekka'; (ihan) 
talon vieressä '(right) beside the house'. Given these facts, it seems preferable to assume that the genitive case of the NP comes from its position as sister of the P head: ${ }^{9}$

$$
[\mathrm{PP} \ldots[\mathrm{P}, \mathrm{NP}-\mathrm{GEN} \mathrm{P}]]
$$

\subsection{NP subject of participial clauses}

In Finnish, participial forms (i.e. those verb forms which are neither finite nor infinitive) can be heads of dependent clauses. There is a large array of participial clauses, all of which have a (more usual) finite clause as a functional equivalent. These participial clauses do not always have an overt subject, in particular when the external argument is a non-generic unspecified human agent (in which case the participle appears in the socalled "passive" form), when it is expressed solely by a so-called "possessive" suffix on the participle, or when it is the relativized element in a participial relative clause.

Whenever there is an NP in subject position, however, it takes the genitive case. Clauses that display this phenomenon may be completive or not, and if not, they must be either circumstantial or relative. A few examples follow with comments. ${ }^{10}$

In (26), the bracketed participial clause is the direct object of the verb uskoo. If it were finite, it would have to be introduced by a complementizer (että 'that'), and have a nominative subject (Pekka) with which its tensed verb would agree (nukkuu in the present, nukkui in the past). Here, however, there is no complementizer, the subject is in the genitive, and the verb has a participial morpheme: either $-v A n$, which expresses the non-anteriority of the process with respect to the finite verb, or -neen, which expresses the anteriority of the process with respect to the finite verb. It is interesting to 
note that both these morphemes contain a vestige of an earlier genitive $(<$ $-v A-\boldsymbol{n} ;<-n e e-\boldsymbol{n})$, which was assigned to the participle as head of the direct object of the finite verb (see $\S 2.6$ ). This $-n$ can no longer be analyzed as a genitive marker, since it does not alternate with the partitive as it otherwise should (Vilkuna 2000:293).

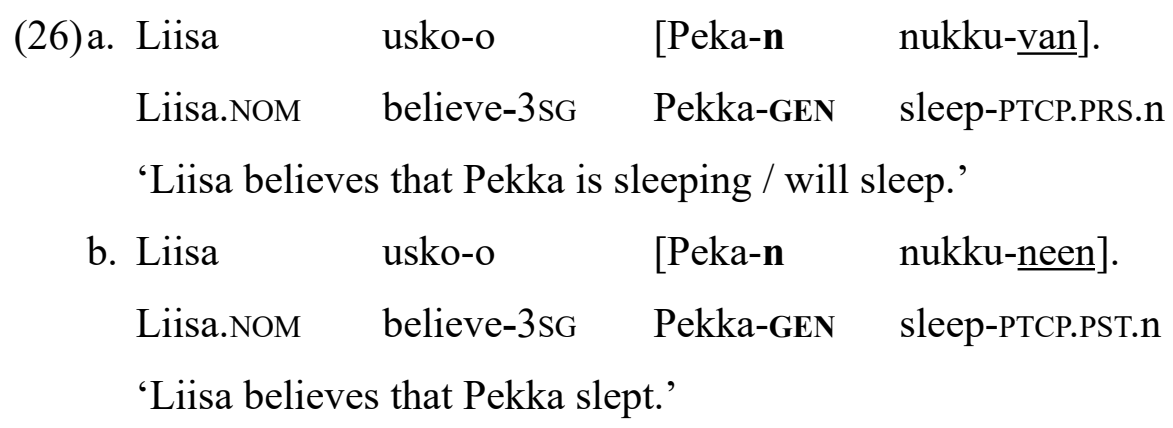

This type of case marking varies in an interesting way in two contexts. In (27a), the finite verb näyttää is inaccusative (does not take an external argument), which implies that Pekka, the external argument of the participle, must appear in the subject position of the finite verb and take nominative case. (Another option would be to replace the participial proposition by a finite one: nayttää siltä, että Pekka nukkui huonosti 'it seems that Pekka slept badly'.) In (27b), on the other hand, it is the participle olevan that is inaccusative. It is therefore a part of its complement, the NP kuolleita, that appears in the subject position of the participle. Since this NP takes the partitive from the outset, and the partitive is not a structural case, it retains this case as subject of the non-finite verb. Hence, the subject of a participle is exceptionally not in the genitive. ${ }^{11}$

\begin{tabular}{|c|c|c|}
\hline (27)a. Pekka & näyttä-ä [nukku-neen & huonosti] \\
\hline Pekka.NOM & seem-3SG sleep-PTCP.PST.n & badly \\
\hline
\end{tabular}



b. Usko-n [kuolle-i-ta ole-van kymmen-i-ä]. believe-1SG dead-PL-PART be-PTCP.PRS.n ten-PL-PART 'I believe that dozens of people died.'

In (28), the bracketed participial clause is a circumstantial adjunct. It is not selected but simply modifies the tensed clause. Again, there is no complementizer, the subject Pekan is in the genitive, and the verb has a participial morpheme: either -essA (known in traditional grammar as the "inessive of the second infinitive"), which expresses the non-anteriority of the process with respect to the finite verb, or $-(t) t U A$ ("partitive of the past passive participle"), which expresses anteriority. This construction is strictly equivalent to a finite clause introduced by kun 'when' where the subject would take the nominative case.

$$
\begin{aligned}
& \text { (28)a. [Peka-n syöd-essä] Liisa läht-i. } \\
& \text { Pekka-GEN eat-PTCP.ssA Liisa.NOM go-PRET.3SG } \\
& \text { 'While Pekka was eating, Liisa went away.' } \\
& \text { b. [Peka-n syö-tyä] Liisa läht-i. } \\
& \text { Pekka-GEN eat-PTCP.(t)A Liisa.NOM go-PRET.3SG } \\
& \text { 'When Pekka had eaten, Liisa went away.' }
\end{aligned}
$$

The structure in (29), where the participle marked by - $m A$ - ("third infinitive") has the abessive case - $t$ t $A$, shows that circumstantial clauses are not always used to express temporal relationships. The subject nevertheless remains in the genitive.

(29) Lähd-i-n [Peka-n huomaa-ma-tta mitään]. go-PRET-1SG Pekka-GEN notice-PTCP-ABE nothing 'I went away without Pekka noticing anything.' 
Finally, though this is not the only possible analysis, the bracketed participial clause in (30) can be treated as relative. In the corresponding finite clause, which would have to be postposed to the $\mathrm{N}$ auto, there would be a relative pronoun referring to this $\mathrm{N}$ and standing as direct object (jonka 'which'), then a nominal subject (Pekka) followed by a tensed verb agreeing with the subject (osti 'bought'). Here, the participial clause has no relative pronoun; the relativized element, i.e. the internal argument of the participial verb, is not realized. Reference to it is established by the relationship obtaining with the $\mathrm{N}$ auto which the participial clause premodifies: the head of this clause, i.e. the participle marker - $m A$-, agrees in case (here inessive) with the $\mathrm{N}$ auto. The subject is in the genitive.

$\begin{array}{llll}\text { (30) Istu-i-n } \quad[\text { Peka-n } & \text { osta-ma-ssa }] & \text { auto-ssa. } \\ \text { sit-PRET-1SG } & \text { Pekka-GEN } & \text { buy-PTCP-INE } & \text { car-INE } \\ \text { 'I was sitting in the car which Pekka bought.' } & \end{array}$

Vainikka's answer (1993:138-139) to the question which syntactic configuration leads to assignment of the genitive to the subject of all these clauses is: specifier of the $\mathrm{V}$ head. This position is hard to maintain. If it were true, one would expect the subject of tensed clauses also to take the genitive. Vainikka accepts this consequence and argues that the situation arises whenever the subject does not agree with the tensed verb. (In case of agreement, it would take the nominative as specifier of Infl, and the genitive should then percolate down to the direct noun object in sister-of-V position, see $\S 2$.6.) In part 3 of this paper, however, I will show that what Vainikka and many other Finnish grammarians analyze as a genitive subject of a personal verb is actually always an oblique modifier of an impersonal verb.

If the subject takes the genitive only in participial clauses, it seems natural to argue that the participle itself, i.e., the Ptcp head, assigns the genitive to its specifier. This is consistent with the partially nominal status 
of participles.

$$
\text { [PtcpP NP-GEN [Ptcp, Ptcp VP]] }
$$

\subsection{Direct NP object of certain kinds of VP}

The Finnish genitive also contrasts with other cases in one last basic dependency relationship. This is the object relationship, i.e. complementization of a V head by an NP. Consider as an initial example:

$\begin{array}{lcc}\text { Pekka } & \text { ost-i } & \text { auto-n. } \\ \text { Pekka.NOM } & \text { buy-PRET.3SG } & \text { car-GEN } \\ \text { 'Pekka bought a car.' } & \end{array}$

The interpretation of the $-n$ on the direct object is a matter of some debate. As table 1 shows, traditional Finnish grammar, which many scholars follow on this point, takes this to be an accusative rather than a genitive case marker. This is how it is usually glossed, and it is traditionally called genetiivinkaltainen akkusatiivi 'genitive-like accusative' or genetiiviakkusatiivi 'genitive-accusative'. Another name for it is accusative1 , in contrast to accusative- 2 which designates the object's nominative case (see below).

The arguments for this approach are based on historical linguistics. Firstly, some Uralic languages (Nenets, Mari, and Southern Saami) have an accusative case in $-m$. In addition, there is good reason to believe that the rule $[-m \rightarrow-n / \ldots$ \# applied during the transition from Proto-Finno-Saamic (or "Pre-Finnic") to Proto-Finnic. Hence, it can be concluded that the object suffix $-n$ comes from a Proto-Uralic accusative $*_{-}-m$, and thus remains an accusative. 
This conclusion is rejected here. First of all, the identity of $-n$ on the direct object needs to be determined synchronically, and must therefore be decided on the basis of synchronic arguments. But there is no synchronic formal reason to distinguish object $-n$ from a genitive. On the contrary, there are positive reasons for identifying this $-n$ with the genitive marker. Kiparsky (2001:320-321) gives the following example: since human pronouns are the only NPs to have an undeniably accusative form $(-t)$, it might be expected that adjectives modifying these pronouns (as parka 'poor' in minä parka 'poor me') would agree with them in the same (accusative) case, as they do with other cases. This does not in fact happen. (One finds, for example, minulla paralla in the adessive, but *minut paran is ill-formed, showing that $-n$ is not an accusative on a par with $-t$ ). Finally, it is far from evident that object $-n$ comes from an accusative *-m. Briefly stated (see Mahieu 2007:163-174 for details), if this were true, Proto-Finnic would have had syntactic transitivity and purely verbal predication. The fact is, however, that today's finite forms derive from earlier verbonominal predicates which are known to assign the genitive to their internal argument as a matter of course (cf. the object of verbal nouns in Celtic). For all these reasons, $-n$ on the object should be treated as a genitive.

As already mentioned, the genitive is not the only case that can affect the direct object. There are several conditions to be met which keep it from marking more than one object in five on average (Hakulinen et al. 2004:1182). The two most frequent cases are the partitive and the nominative, while the accusative is much rarer still.

Which of these cases is chosen can be seen as the result of a hierarchy of constraints which can be stated as follows. Firstly, any one of the following four conditions will suffice for the object to appear in the partitive: (1) the sentence is in the negative; (2) the VP denotes a process without a "telos", i.e. without an end goal; (3) the process denoted by the VP is viewed as "imperfective", i.e. as in the process of coming about; (4) the object denotes 
an indeterminate quantity of something. ${ }^{12}$ Each of these criteria is illustrated in (33). In (33a), the VP is within the scope of negation which, in Finnish, is an inflectional head agreeing with the subject. In (33b), the VP is intrinsically atelic. In (33c), the verb is telic but viewed as not having reached its telos. In (33d), the object is a quantitatively indeterminate mass noun.

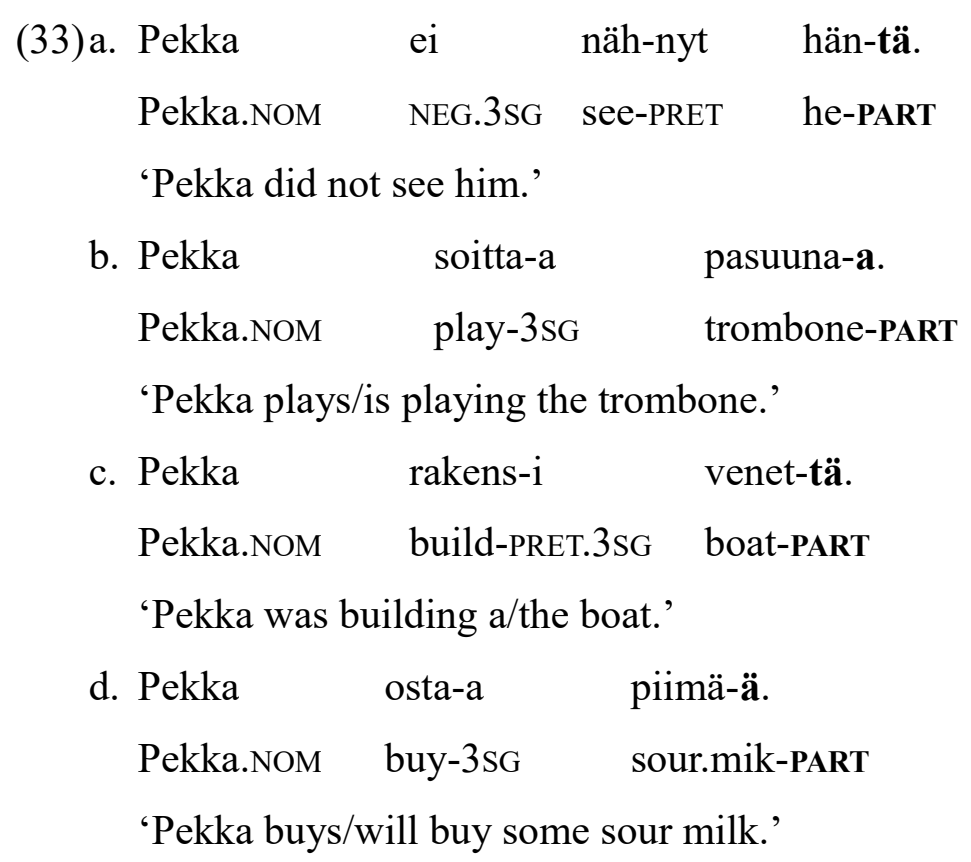

Secondly, whenever none of the conditions for assigning the partitive is met, it suffices that the object should be in the plural for it to take the socalled "nominative plural" morpheme $-t$. The analysis of this morpheme is not without difficulties of its own. It is open to question whether it truly has the plural number feature and the nominative case feature, and whether it is not rather an allomorphic variant of the plural $(-i-)$ before nominative case $(\varnothing)$, or even something quite different, e.g. a "specific plural" marker, as Renault (1991:42-49) suggests. 


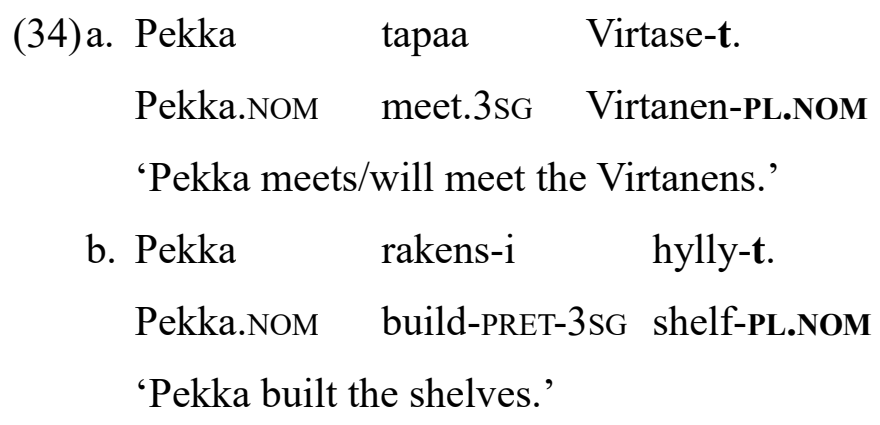

Thirdly, if the partitive is not required and there is no plural marker, it will suffice that the object be a human pronoun for it to take accusative $-t$. In all, only seven Finnish lexemes can take this case: the six (intrinsically human) personal pronouns and the human interrogative pronoun $k u k a$ 'who?'.

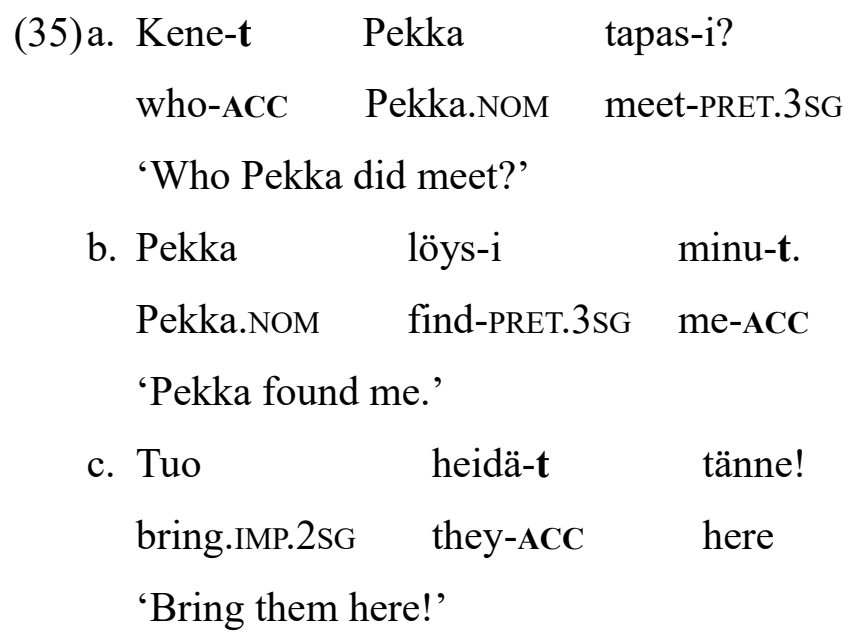

Fourthly, if the partitive is not required and the object is a singular noun, it will suffice that there be no nominative subject in the sentence for the object itself to take the nominative. This situation occurs in first and second person imperatives, in so-called "passive" sentences where the verb inflection is exempted from specifying a subject, the latter being interpreted as a non-generic human agent, and in infinitive clauses complementing an impersonal verb. Thus, the object is unquestionably in the nominative in 
(36), rather than in a special form of the accusative, as traditional grammar would have it (Kiparsky 2001:319-320).

$$
\begin{aligned}
& \text { (36)a. Vie (sinä) koira ulos! } \\
& \text { take.IMP.2SG you.NOM dog.NOM out } \\
& \text { '(You,) take the dog out!' } \\
& \text { b. Nyt vie-dä-än koira ulos. } \\
& \text { now take-PASS-one dog.NOM out } \\
& \text { 'Now we will take the dog out.' } \\
& \text { c. Täyty-y vie-dä koira ulos. } \\
& \text { have.to-3SG take-INF dog.NOM out } \\
& \text { 'The dog has to be taken out.' }
\end{aligned}
$$

Fifthly and finally, if none of the conditions for assigning the partitive is met, the object is a singular noun, and the sentence contains or can contain a nominative subject, the object takes the genitive case. This is what happens in (32) and again in (37) below. The phrase "can contain" is essential to the rule, as subject pronouns are only expressed for emphasis in the first and second persons. The only sentences in which the object takes the genitive even when there can be no subject in the nominative are "generic" sentences, an example of which appears in (38).

$$
\begin{aligned}
& \text { (37)a. Pekka on löytä-nyt avaime-n. } \\
& \text { Pekka.NOM be.3sG find-PTCP.PST key-GEN } \\
& \text { 'Pekka has found the key.' } \\
& \text { b. Hän soitta-a tämä-n } \\
& \text { he.NOM play-3sG this-GEN } \\
& \text { 'He will play this sonata.' }
\end{aligned}
$$


c. (Me) makso-i-mme koko lasku-n.

(we.NOM) pay-PRET-1PL all bill-GEN

'We paid the whole bill.'

(38)

$\begin{array}{llll}\text { Sieltä } & \text { saa } & \text { helposti } & \text { malaria-n. }{ }^{13} \\ \text { from.here } & \text { get.3sG } & \text { easily } & \text { malaria-GEN }\end{array}$

'One easily catches malaria here.'

To conclude this overview of the main data, it should be noted that in an infinitive clause which complements or modifies a noun, the object will not usually appear in the genitive. If it cannot be assigned either the partitive or the accusative, it takes the nominative. Apparent exceptions can be explained (Ikola 1964:66-80).

On the other hand, in infinitive clauses which complement a finite verb or are separated from a finite verb only by other non-finite clauses, the object takes the genitive whenever the finite verb has a nominative subject. An example of this kind of "long-distance" dependency (Mahieu 2008) is given in (39).

(39)a. (Minä) yritä-n muista-a teh-dä harjoitukse-n.

(I.NOM) try-1SG remember-INF do-INF exercise-GEN

'I will try to remember to do the exercise.'

b. Yritä nyt muista-a teh-dä harjoitus!

try.IMP.2SG now remember-INF do-INF exercise.NOM

'Now try to remember to do the exercise!'

From a typological perspective, the case marking system for verb arguments in Finnish is quite unusual. Once the partitive and plural forms, whose use depends on semantic factors, are set aside, the system can be called "antiergative", a term used by Comrie (1975). The distribution of the genitive forms a mirror image of the ergative case-marking system as found 
in syntactically accusative languages: the object is only marked when there is an unmarked subject. It may be added that this "antiergativity" is contravened by the human pronouns which follow an accusative marking type. ${ }^{14}$

(40)a. ACCUSATIVE SYNTAX, ACCUSATIVE CASE-MARKING

$$
\begin{array}{lll}
\mathrm{S} \text { (nominative) } & \mathrm{V} & \\
\mathrm{S} \text { (nominative) } & \mathrm{V} & \mathrm{O} \text { (accusative) } \\
& \mathrm{V} & \mathrm{O} \text { (accusative) }
\end{array}
$$

b. ACCUSATIVE SYNTAX, ERGATIVE CASE-MARKING

$$
\begin{array}{lcl}
\mathrm{S} \text { (absolutive) } & \mathrm{V} & \\
\mathrm{S} \text { (ergative) } & \mathrm{V} & \mathrm{O} \text { (absolutive) } \\
& \mathrm{V} & \mathrm{O} \text { (absolutive) }
\end{array}
$$

c. ACCUSATIVE SYNTAX, ANTIERGATIVE CASE-MARKING

$$
\begin{array}{lcl}
\mathrm{S} \text { (absolutive) } & \mathrm{V} & \\
\mathrm{S} \text { (absolutive) } & \mathrm{V} & \mathrm{O} \text { (antiergative) } \\
& \mathrm{V} & \mathrm{O} \text { (absolutive) }
\end{array}
$$

Comrie $(1975,1977: 7)$ provides a purely functionalist interpretation of antiergativity: the distribution of $-n$ can be explained simply by a need to distinguish subject and object when both are present in a sentence. This explanation leaves something to be desired. It cannot explain why one marking type occurs rather than another; it cannot explain the existence of split distributions; it cannot explain why one morpheme rather than another is chosen to mark a given relationship; and finally, it does not take into account the fact that subject and object can be distinguished in various other ways, even in a language with loose word order like Finnish.

More complex explanatory hypotheses have since been proposed (see particularly Milsark 1985; Taraldsen 1986; Vainikka 1989, 1993; Maling 1993; Reime 1993; Toivainen 1993; Nelson 1998; Mahieu 2007), but they 
cannot be discussed here.

There is at least one point that can easily be defended: the genitive is assigned to the object for syntactic reasons; it has no more meaning content than the nominative with which it alternates automatically. Furthermore, the syntactic configuration for its assignment cannot be reduced to any single one of the configurations discussed here thus far.

In particular, it is clear that the source of the object genitive is not the same as that of the subject genitive. This was the theory proposed by Vainikka (1989:151-181), who saw the genitive appearing as specifier of V in both cases, and presumably percolating down to sister-of-V position whenever the subject is raised to agree with an Infl head. If this were true, one would expect that both subject and object could never bear the genitive in the same clause. While this expectation is met in finite clauses, it is contradicted in participial clauses. In (41), both verb arguments in the bracketed completive can be seen to bear genitive marking. (Here again, the object would only be in the nominative if there were no possible nominative subject of the finite verb.) Given these facts, it must be assumed that the genitive is assigned to subject and object in different configurations. With regard to the object, the simplest hypothesis would be to assume that assignment takes place directly in sister-of-V position as shown in (42).

$$
\begin{array}{llll}
\text { Tiedä-n } & \text { [Peka-n } & \text { osta-neen } & \text { auto-n]. } \\
\text { know-1SG } & \text { Pekka-GEN } & \text { buy-PTCP.PST.n } & \text { car-GEN }
\end{array}
$$

'I know that Pekka bought a car.'

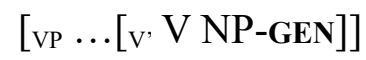

\subsection{Postposed NP modifier of certain types of VP}

Finally, the genitive expresses a somewhat marginal but nonetheless 
unexpected dependency relationship under conditions which are nearly identical to the ones which lead to the genitive being assigned to objects. The relevant context is the modification of a VP by an NP denoting quantity, often distance, duration, or frequency. The rule is as follows: if the VP is not within the scope of negation, and the sentence has or can have a subject in the nominative, then the quantifying modifier takes the genitive, provided it is not invariable (as joka päivä 'every day', which is always nominative). Otherwise, it takes either the partitive or the nominative.

\author{
(43)a. Minä juokse-n kilometri-n. \\ I.NOM run-1SG kilometre-GEN \\ 'I will run a kilometre.' \\ b. E-n juokse kilometri-ä. \\ NEG-1SG run kilometre-PART \\ 'I will not run a kilometre.' \\ c. Juokse vielä kilometri! \\ run.IMP.2SG still kilometre.NOM \\ 'Run one more kilometre!' \\ d. Nyt juos-ta-an kilometri. \\ now run-PASS-one kilometre.NOM \\ 'Now we will run one kilometre.'
}

The only real difference with respect to the object marking system is that the quantifying modifier does not take the partitive if the VP is atelic or the viewpoint is imperfective. For example, one finds odotin tunnin 'I was waiting for an hour' with genitive modifier, but odotin hänẗ̈ 'I was waiting for him' where the object must be partitive. These may be compared with odota tunti! 'wait for an hour', where the modifier is in the nominative in the absence of any possible nominative subject.

In view of these data, it might be assumed that the case marking of the 
modifier takes place within the same syntactic configuration as the marking of the object, with the NP taking the genitive in sister-of-V position. This does not, however, seem to be true. The VP can quite easily have a direct object in addition to the quantifying modifier, as in (44).

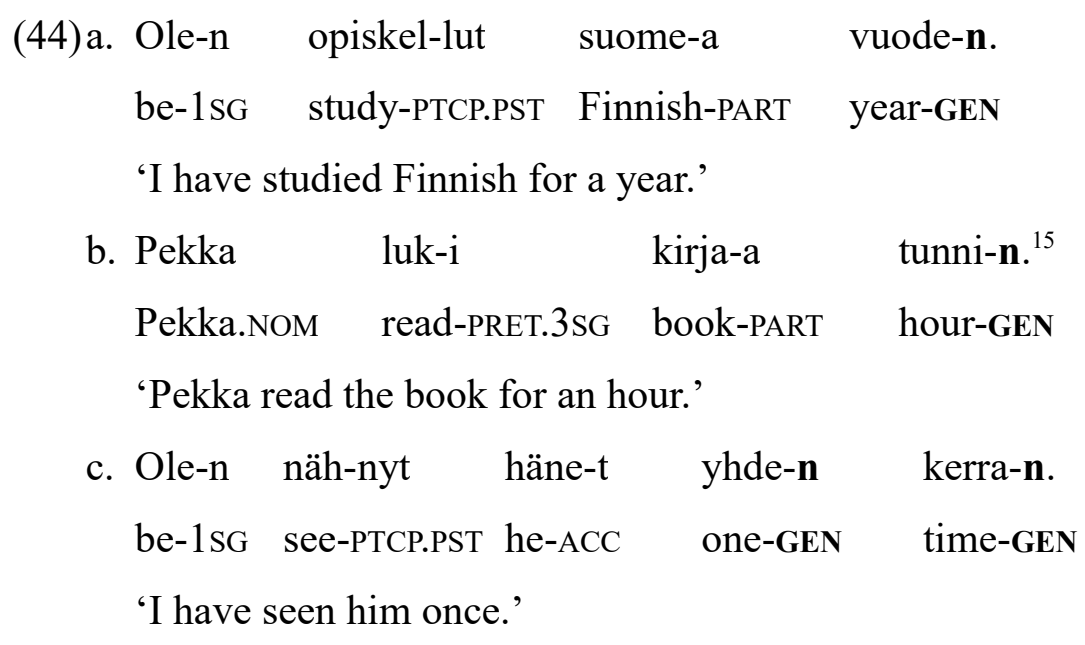

All in all, it would be better to allow that the quantifying modifier does not take the genitive in sister-of-V position but rather as an adjunct following the VP, as represented in (45).

$$
\text { (45) }[\mathrm{vP}[\mathrm{vP} \ldots[\mathrm{v}, \mathrm{V} \ldots] \mathrm{NP}-\mathrm{GEN}]]
$$

This section has made it clear that there is enough evidence for the conclusion that the genitive in Finnish is neither the case of possession nor, more widely speaking, the case of any given semantic operation. It is a structural case standing in a complex system of contrasts with other cases and reflecting an irreducible range of syntactic relationships. 


\section{The "dative-genitive" issue}

A good number of ordinary Finnish constructions contain an $-n$ morpheme which recent grammars (starting with Hakulinen et al. 2004) do not distinguish from the genitive. It can be shown, however, that this morpheme is not a structural case but rather a semantic case with dative sense, corresponding to a $\mathrm{P}$ category in syntactic structure. In traditional Finnish grammar, this case, formally identical to the genitive, was called "dativegenitive".

The constructions in which this $-n$ appears will now be described, and the main reasons for not treating it as a structural case will be set out. Its relationship to the genitive will then be examined from a historical perspective, with a view to providing a general explanation of the diachronic origin of the genitive case. It will be glossed "DAT.GEN" to distinguish it from the genitive proper.

\subsection{The necessive construction}

As a general rule, the necessive construction consists of a necessive predicate and its infinitival complement. The "necessive predicate" can be defined as follows: "a single verb like täytyy, pitää, tarvitsee 'must, have to, need to', kannattaa 'be worthwhile', sopia 'be suitable', or a copular construction like on hyvää / sopiva / turha / pakko 'be good / suitable / in vain / a necessity'. One [special] type of necessive construction consists of a copula and the [so-called] passive participle of the verb, as in on tehtävä 'has to be done"' (Laitinen and Vilkuna 1993:24). The important point to note here is that a necessive construction can always be preceded by an NP with the $-n$ suffix expressing the experiencer of the obligation. 


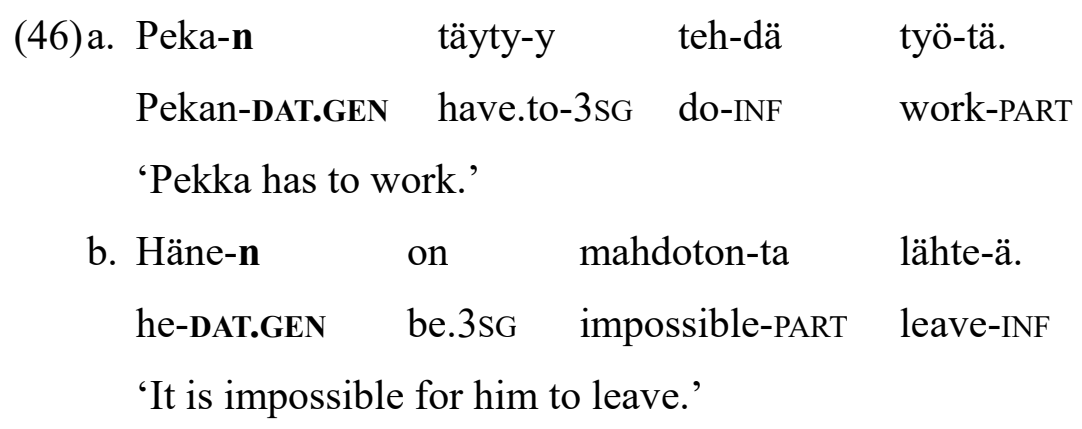

If this NP were the genitive subject of the necessive predicate, it should not for independent reasons be possible to delete it in the third person. Only the first and second person forms are allowed not to have a full subject in independent sentences. Yet it is in fact possible to delete the experiencer, sometimes with insertion of another topic. Thus, (36c) is an example of a necessive sentence without an experiencer expressed. In this case, the reference to the implicit subject of the infinitive is uncontrolled, hence arbitrary. Consequently, it can be affirmed that necessive predicates are impersonal (which explains why they are in the third person by default), and the - $n$-bearing NP is no more than a predicate modifier.

Moreover, if the case of this modifier were really genitive, it would have no stable meaning (see part 2) and could not alternate with any semantic case. Yet it has in fact dative meaning (the obligation falls to this or that person) and can alternate with the allative -lle. Where alternation is allowed, it is furthermore associated with a meaning difference which is too complicated to be discussed here. Good treatments of this subject can be found, for example, in Laitinen and Vilkuna (1993:33-34) and Hakulinen et al. (2004:878).

Experiencer $-n$ is therefore not a genitive but rather a semantic case with dative sense. This means that, unlike the genitive, it is not the morphological reflex of a syntactic dependency relationship. It is itself the manifestation of a syntactic category connecting the NP to the rest of the sentence. The fact that the semantic cases are derived from former postpositions which have 
gradually been cliticized on nouns (Korhonen 1996:195-206, 219-234) gives grounds for assuming that the semantic cases are $\mathrm{P}$ heads, and this can be widely confirmed by synchronic analysis. ${ }^{16}$ It can therefore be concluded that the experiencer in the necessive construction is the complement of a dative $\mathrm{P}$ head, that this $\mathrm{P}$ head is realized by the case marker $-n$, and that the PP in which the experiencer is embedded is an adjunct to the necessive VP.

\subsection{The permissive construction}

The so-called "permissive" construction minimally consists of one of the five permissive verbs and its infinitival complement. These verbs are antaa 'let (someone do)' (the primary meaning of this verb being 'give'), sallia 'permit', käskeä 'order', suoda 'grant', and more marginally luvata when it means 'authorize, allow' (and not 'promise'). The permissive verb is usually followed by an $-n$-bearing NP which expresses the experiencer of the permission.

$$
\begin{array}{llll}
\text { Liisa } \quad \text { anto-i } & \text { Peka-n } & \text { men-nä. } \\
\text { Liisa.NOM } \quad \text { let-PRET.3SG } & \text { Pekan-DAT.GEN } & \text { go-INF } \\
\text { 'Liisa let Pekka go.' } & &
\end{array}
$$

Here again, it is clear that the NP marked by $-n$ is neither a subject nor an object in the genitive. If it were, given that a verb in the infinitive never has an overt subject other than one governed by an ECM (Exceptional Case Marking) verb, it ought to alternate in a paradigm of object cases (see $\S 2.6$ ). Yet $-n$ does not in fact vary with context and can be found within the scope of negation (en antanut Pekan mennä 'I didn't let Pekka go'), on human pronouns (Liisa antoi hänen mennä 'Liisa let him go'), and in imperatives (anna Pekan mennä! 'let Pekka go!'). 
It should also be impossible to delete the marked NP, and the case marker should have no meaning. Yet it is in fact possible for the experiencer of permissive sentences to be omitted (Hakulinen et al. 2004:498), and - $n$ clearly has basic dative value, just as in necessive sentences (permission is granted to someone or other). It is furthermore well known that permissive sentences derive from the reanalysis of ordinary sentences where the $-n$ bearing NP was the Beneficiary of the verb antaa 'give', as in anna minun syödä ruokaa! 'let me eat some food!' < anna minun ruokaa syödä! 'give me some food to eat!' (expressed in contemporary Finnish by anna minulle ruokaa syödäkseni!). (On this point, see Leino 2003.)

Given these facts, it can reasonably be concluded that the $-n$ marking the experiencer in the permissive construction is not a genitive but again the manifestation of a dative $\mathrm{P}$ head having the function of joining its complement, the experiencer, to the rest of the sentence. The PP is thus an adjunct to the permissive VP.

\subsection{The experiencer construction}

In what is called the "experiencer construction" here, a predicate expressing a feeling or sensation is preceded by an NP marked by - $n$ designating the experiencer. The predicate is composed of one of the verbs on 'is', tulee 'comes', or käy 'goes', followed by a noun, an adjective, or an adverb denoting what is felt. This construction is less susceptible to manipulation than the preceding ones, but it is even more obvious that the initial NP does not have structural genitive marking.

\begin{tabular}{|c|c|c|}
\hline (48)a. Peka-n & ol-i & jano \\
\hline Pekka-DAT.GEN & be-PRET.3SG & thirst.NOM \\
\hline
\end{tabular}

'Pekka was thirsty / hot.' 
b. Minu-n tule-e sääli / ikävä hän-tä.

I-DAT.GEN come-3SG pity.NOM sorrow.NOM he-PART

'I feel sorry for him. / I miss him.'

c. Liisa-n käv-i hyvin / hassusti.

Liisa-DAT.GEN go-PRET.3SG well funnily

'Things went well for Liisa. / Liisa was unlucky.'

First of all, the NP can be deleted, as in on kuuma '[the weather] is hot', häntä käy sääliksi 'he is a sorry sight to see, in a pitiful state', or hyvin kävi 'it went well'. It can thus be treated as a predicate modifier. In addition, it is almost inconceivable that $-n$ should be the meaningless reflex of a syntactic dependency relationship here; it is clearly this case which relates the initial NP syntactically and semantically to the predicate. In its absence, the nature of this relationship could not always be inferred as can be seen from the question mikä sinun on? 'what's up with you?'. Finally, the experiencer case can often be replaced by a locative case as in hänelle kävi hassusti 'she was unlucky'. In short, the experiencer again appears as the complement of a dative $\mathrm{P}$ head projected as a PP adjunct to the predicate of feeling.

\subsection{The "dative-genitive" predicate}

In the construction exemplified by (1b) and repeated below as (49a), the semantic role of the - $n$-bearing NP is not that of experiencer but rather that of possessor. This NP is furthermore part of the predicate whose subject designates the thing possessed.

\begin{tabular}{|c|c|c|}
\hline (49)a. Auto & on & Peka-n. \\
\hline car.NOM & be. $3 \mathrm{SG}$ & Pekka-DAT.GEN \\
\hline
\end{tabular}


$\begin{array}{lll}\text { b. Kene-n } & \text { auto } & \text { on? } \\ \text { who-DAT.GEN } & \text { car.NOM } & \text { be.3SG }\end{array}$

'Whose car is it?'

Once again, $-n$ cannot be treated as a meaningless case marker. Unlike Pekan auto 'Pekka's car' where the case marked by $-n$ is assigned for purely structural reasons and independently of the semantic role assumed by the modifier (see $\S 2.1$ ), here it is the element which establishes the syntactic and semantic relationship between the two NPs. Furthermore, the dative sense is again recognizable (a thing belongs to someone or other).

Given these facts, it can be concluded that the $-n$ marker is the realization of a P head taking the possessor as its complement. The PP is itself the complement of the verb olla 'be', and the NP expressing the thing possessed is realized as the subject of this verb. ${ }^{17}$

\subsection{The loose "dative-genitive"}

The four constructions described above are the only ones in the standard language to use the $-n$ case marker with dative sense. This use is also found in at least one other construction in dialect which is cited here both because it has been a topic of prior research (see in particular Huumo and Inaba 1997), and because it provides support for the positions taken here.

In this construction, the - $n$-bearing NP has the semantic role of possessor and appears sentence-initially at a distance from the NP expressing the thing possessed. The following examples are taken from Huumo and Inaba (ibid.).

$$
\begin{aligned}
& \text { (50)a. Peka-n on auto rikki. } \\
& \text { Pekka-DAT.GEN be.3sG car.NOM broken }
\end{aligned}
$$

'Pekka's car is broken.' (dialectal) 


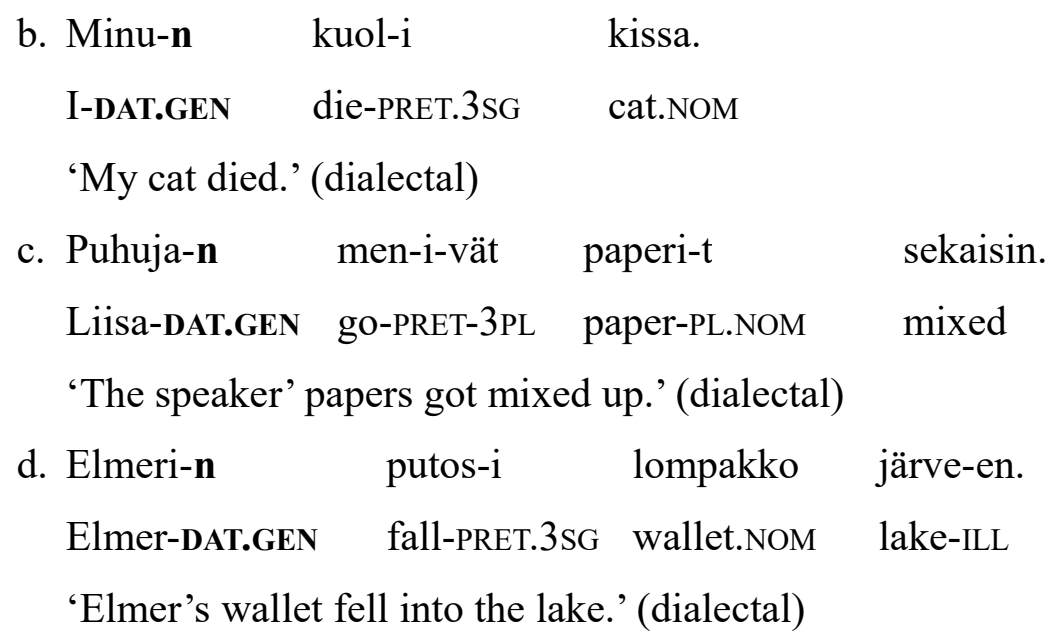

At first glance, this construction might be analysed as resulting from inversion involving the movement of the verb to a position between the head of a complex NP subject and its preposed genitive modifier. (50a) would thus derive from [Pekan auto] on rikki. Huumo and Inaba (ibid.) provide numerous convincing arguments to show that this analysis is incorrect.

Here are a few of these arguments. First of all, the semantic role of the NP marked by $-n$ is restricted to that of possessor in the strict sense of 'owner'. This would be incomprehensible if the NP were really a preposed genitive modifier of a $\mathrm{N}$ head. The situation is thus the same as in 3.4: the case marked by $-n$ is used to indicate to whom something belongs. Furthermore, the NP marked by $-n$ is not always linked to the subject. In pojan meni tikku sormeen 'a splinter got stuck in the boy's finger', the possessive relationship is established with the locative complement. Analysis as inversion is thus unsuitable, and the initial constituent is more like an added element. Finally, there is good reason to think that sentences like (50) are related to an earlier possessive construction, still found in Mordvin and Mari, where the case marked by $-n$ was clearly semantic with dative sense. The replacement of this case in Finnic by the external locative cases was probably responsible for marginalizing "loose dative-genitive" 
sentences. Sentences like Pekalla on auto rikki, or minulta kuoli kissa, are in any case much more common. In short, we may conclude that the case marked by $-n$ in (50) constitutes a dative $\mathrm{P}$ head with the possessor as its complement.

\subsection{The historical background}

It may be helpful at this point to look briefly at the links between the structural genitive case described in part 2 and the semantic dative case presented in this section. The need to distinguish the two synchronically does not of course imply that they cannot have a common origin. There are two positions on this question, the second of which currently prevails.

The first, discussed in Hakulinen (1968:86), asserts that there is no historical relationship between the two case forms. The structural genitive case is assumed to have existed in Proto-Uralic where it had the same form, *-n, as in modern Finnish. It has on occasion been suggested that this ProtoUralic genitive may itself have come from a very ancient adjectival derivational morpheme which can still be observed in Mari, Mordvin, and Southern Saamic. (Thus in Mari, lun is either the genitive of the noun 'bone' or an adjective meaning 'made of bone'.) The "dative-genitive" in turn is thought to derive from a Proto-Uralic $*_{-} n$ marking the lative case. This morpheme is also assumed to have played a role in the creation of the two directional cases, the illative $\left(-h V n<*_{-s e}+*_{-}-n^{\prime}\right)$ and the allative $\left(-l l e<*_{-} l e\right.$ $\left.+*_{-n}\right)$. It must then have merged formally with the genitive in the transition to Proto-Finnic as a result of the process $[-n \rightarrow-n]$. In Old Finnish, it must have remained productive and continued to contrast with the genitive as dative for a long period (see Hakulinen ibid. for the data). It later lost ground to the two directional cases.

There are at least two problems with this first approach. The notion that 
the Proto-Uralic lative must have been a palatalized *-ń, i.e. formally distinct from the hypothetical genitive ${ }^{*}-n$, is totally ad hoc. Vestiges of the "lative-dative" exist in all Uralic languages, and invariably allow reconstruction as non-palatal $*_{-} n$. Furthermore, the structural genitive case in $-n$ is totally absent from some branches of Uralic, in particular ancient branches like Ugric and Permian. This would mean that the structural genitive must have been lost there.

The second approach is much more convincing. It postulates that the two cases are historically related (Itkonen 1968:202), and that the structural genitive is the outcome of a long process of grammaticalization of the original Proto-Uralic lative (Korhonen 1996:222-224). This process is likely to have been as follows: Proto-Uralic had no genitive, but it did have a lative case marked by $*_{-} n$, still visible in the Finnish illative $-h V \boldsymbol{n}$ and the Mari dative -lan, etc. This semantic case must have quickly acquired a new dative value which can be observed in many Finno-Ugric languages. It must still have been present in Old Finnish, where $-n$ was often used like the modern allative, and has reached modern Finnish in the constructions described in part 3 of this paper.

At some stage, certainly after the Ugric and Permian branches had split off, the lative-dative must have begun to be applied to possessors, not only in the possessive construction (as today in Mordvin and Mari) but also in adnominal contexts. According to Korhonen (ibid.), "it is possible that the dative (or the lative in the dative function) started to be used also as an adnominal case in the possessive function if the possessivity was emphasized, or if the referent of the possessive attribute was animate, human, definite, or pronominal. Otherwise, the case of the possessive was the nominative. According to this scenario, the [evolution] would have been similar to that in Hungarian, where the dative with suffix -nak/-nek has also taken the function of a genitive."

In its adnominal use, the genitive of possession deriving from the lative- 
dative must ultimately have been desemanticized and become a simple dependency marker, i.e. a structural case. In this form, it now appears in an irreducible range of contexts in Finnish, as has been seen in part 2. In contrast, the uses presented in this section, which are relics of what the case marked by $-n$ originally was before it became grammaticalized, are losing ground to the locative cases, as might be expected. This process has reached its end in the possessive construction, as Finnish uses only the adessive and not the $-n$ case (see part 4 ).

There are two features that support the likelihood of the second scenario. First of all, as Korhonen (ibid.) points out, the line of development [lative > dative $>$ genitive] is quite natural from a typological perspective. In addition, the thesis that structural cases come from the grammaticalization of semantic ones, and these ultimately from adpositions, has been widely accepted for some time (see for example Lehmann 1985:304).

\section{The possessive construction}

In the Finnish possessive construction, the possessor, i.e. the entity whose personal ambit is said to include the entity designated as the thing possessed, is an NP bearing, not the case marker $-n$ as in Mordvin and Mari, but the external static locative case, the adessive. When the possessor is inanimate, the adessive case is often replaced by the corresponding internal case, the inessive. This contrast is illustrated in (51).

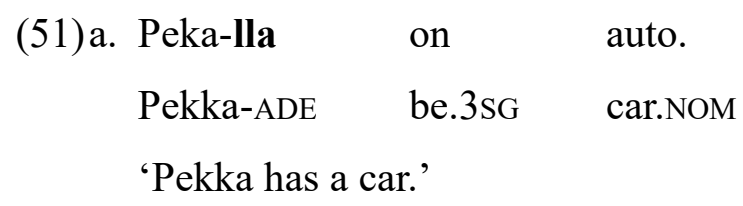



b. Auto-ssa
on
uude-t
renkaa-t.
car-INE
be.3SG
new-PL.NOM
wheel-PL.NOM

'The car has new wheels.'

A superficial look at the Finnish possessive construction might lead to the assumption that it is nothing but a locative inversion. Rather than a transitive structure involving a verb 'have', this construction would then have an initial PP, the verb 'be', and a subject NP in the nominative. The realization of the $\mathrm{P}$ head, i.e. the case marking the possessor, would retain its locative sense, and the literal meaning of the construction would be 'at Soand-So is this'. In short, the possessive construction would thus be a subtype of existential sentence, and the structure of the sentences in (51) would be exactly the same as that of the ones in (52).

$$
\begin{aligned}
& \text { (52)a. Kadu-lla on auto. } \\
& \text { street-ADE be.3SG car.NOM }
\end{aligned}
$$

'There are two people in the car.'

This approach yields contradictory results for several manipulations. Let us look first at the manipulations in question and then try to provide an explanation for this situation.

\subsection{Contra inversion}

The first manipulation is pronominalizing the thing possessed. When the thing possessed is a noun, the fact that it takes nominative case proves 
nothing regarding its syntactic function (see $\S 2.6$ ). On the other hand, the pronominal form is discriminatory as it must be accusative in this context. On this basis, it can be concluded that the postverbal constituent is the direct object of a transitive head.

Peka-lla on häne-t.
Pekka-ADE be.3SG she-ACC
'Pekka has her.'

By way of contrast, the inverted subject of an existential sentence can under no circumstances take the accusative. The nominative would be preferred, but the resulting sentence is not fully acceptable since the inverted subject of existential sentences is supposed to be indefinite, as in the example *kadulla on hänet vs. ?kadulla on hän '?there is he in the street'.

The second manipulation changes the order of the two constituents with respect to the verb. When applied to an existential sentence, this operation clearly changes the way in which the information is distributed (and the definiteness of the subject in translation), but the sentence has approximately the same meaning content. Thus, kadulla on auto 'there is a car in the street' contrasts with the non-existential sentence auto on kadulla 'the car is in the street'. If the possessive construction is a kind of existential sentence, it should behave in the same way, i.e. there should be little to distinguish Pekalla on auto 'Pekka has a car' from another sentence, auto on Pekalla, meaning something like 'the car is Pekka's'. This is not the case, however. Changing the order completely changes the meaning of the sentence, which no longer expresses a possessive relationship: 


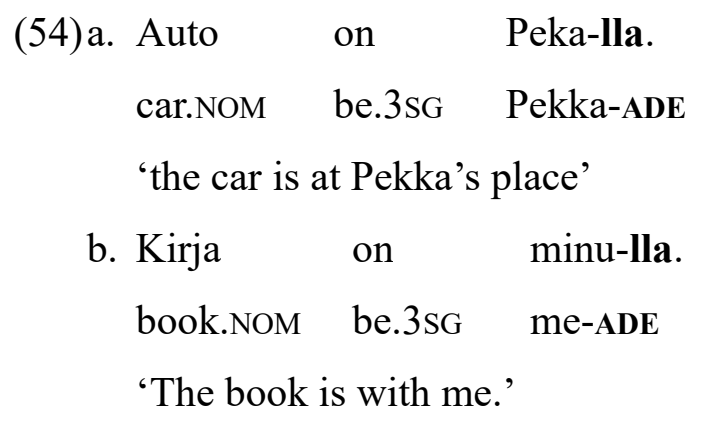

At this point, the conclusion can be drawn that not only is the possessive construction syntactically transitive, but furthermore its possessive sense is not just the sum of the meaning of a static locative case ('at So-and-So') and the verb of existence ('is this'). Instead, the possessive interpretation arises from a specific relationship existing between these two constituents in a specific, apparently non-existential syntactic structure.

The third manipulation is more complex but equally telling. It is based on the contrast shown in (55). In (55a), the subject qualifies as antecedent of the possessive suffix on the locative complement. In (55b), a locative inversion, the initial locative complement cannot qualify as antecedent to the same suffix on the inverted subject, and the sentence is therefore illformed. The explanation for this contrast is the fact that Binding Principle A is violated in (55b). Given that possessive suffixes are anaphoric, they must be bound, i.e. c-commanded by a coreferent NP, in their binding domain. (55a) respects this principle: the NP subject locally c-commands the anaphoric constituent. (55b), by contrast, violates it: since the NP in the locative case is embedded in a PP, it cannot c-command the anaphoric constituent.

$\begin{array}{lll}\text { (55)a. } \text { Kapteeni }_{\mathrm{i}} & \text { nouse-e } & \text { laiva-a-n } \underline{\text { nsa }_{\mathrm{i}} .} \\ \text { captain.NOM } & \text { go.up-3SG } & \text { boat-ILL-pX.3SG }\end{array}$

'The captain gets in his $_{\mathrm{i}}$ boat.' 
b. ${ }^{*}$ Laiva-an $_{\mathrm{i}}$ nouse-e kapteeni-nsa ${ }_{\text {i }}$.

boat-ILL go.up-3SG captain.NOM-PX.3SG

('*In the boat gets its $_{\mathrm{i}}$ captain.')

This being established, the manipulation consists of associating an anaphoric constituent with the thing possessed in the possessive construction. If this construction has the same structure as existential sentences, the possessor must also be embedded in a PP and the result should be ill-formed. Yet as observed by Nikanne (1993:81-83) confirmed by (56), the result is well-formed. This means that the possessor (the NP in the locative case) is not embedded in a PP.

(56)a. Kansalais-i-lla $a_{i}$ on uusi pääministeri-nsä ${ }_{i}$. citizen-PL-ADE be.3SG new.NOM prime.minister.NOM-PX.3SG 'The citizens $s_{i}$ have their ${ }_{i}$ new prime minister.'

b. Joka kiele-ssä ${ }_{i}$ on oma-t sana-nsa ${ }_{i}$. each language-INE be.3SG own-PL.NOM word.PL.NOM-PX.3PL 'Each language ${ }_{\mathrm{i}}$ has its $_{\mathrm{i}}$ own words.'

We can therefore conclude that in the Finnish possessive construction, not only does the postverbal constituent behave like the object of a nonexistential verb, but the preverbal constituent behaves like the subject of the sentence. The problem then is to determine why this subject is in the locative (see in the next section).

The fourth and last manipulation to be discussed here consists of trying to use the possessive construction in sentences which do not have a possessor in the strict sense. If this construction were a locative inversion, this would in all likelihood be impossible. Indeed, when a language without a verb 'have' uses such a strategy, it does so primarly to express a relationship of ownership, not simply of having in one's possession. This is 
in fact true of the other Uralic languages (Huumo and Inaba 1997:39-42; Inaba 1998:167-169). Remarkably, however, the Finnish possessive construction admits all the semantic functions of a verb 'have':

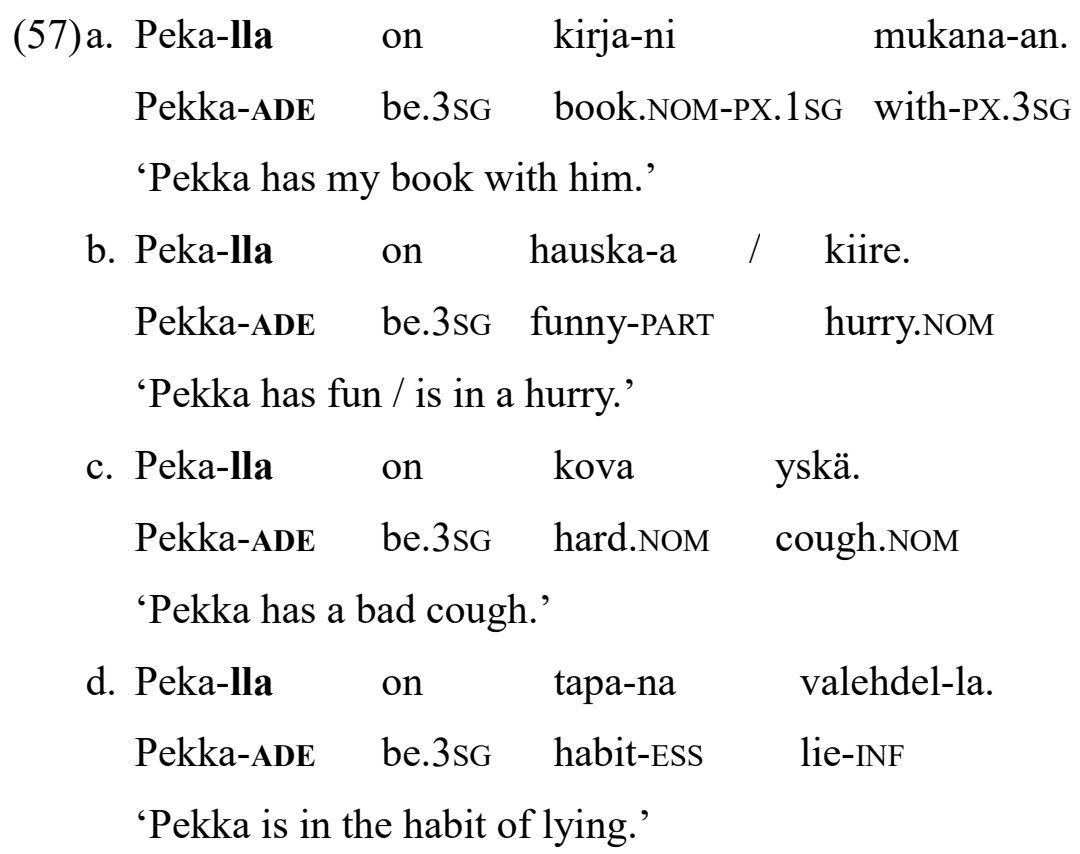

The overall conclusion is thus that, while the forms used in the Finnish possessive construction have the appearance of a locative inversion, the results of submitting this construction to various manipulations suggest a [SVO] structure where the verbal head has the semantic content of a verb 'have'.

Diachronically speaking, it is likely that the original structure was a locative inversion which has since been reanalyzed. It is a fairly common observation that syntactic relationships, given their immaterial nature, evolve more quickly than morphology, which is naturally conservative. Should it therefore be assumed that morphology is synchronically unmotivated, that surface forms are only the remains of an earlier syntactic organization? Not necessarily: in the final section of this paper, I will propose an analysis of the possessive construction that synchronically 
resolves the contradictions set out above.

\subsection{A transformational analysis}

A fairly unsatisfactory way to account for the data synchronically would be to allow for two different homophonous verbs of the form olla, each as a separate lexical entry. One would be the verb 'be' and the other, the verb 'have'. The latter would have the inherent property of assigning locative case to its subject. Since this case is neither structural nor semantic, it will need to be assigned some third status, for instance lexical case, which immediately brings to mind the "quirky subjects" of Icelandic.

There is, however, another solution that is both more economical and more elegant. The starting point, taken from a paper by Benveniste (1966:187-207), is this: the verb 'have' is not or.iginal in the languages where it exists. 'Have' must rather be the spell-out of the verb 'be' plus a prepositional component. In other words, languages cannot be divided into those which have and those which do not have a verb 'have'. There are only languages which incorporate a P head into the verb 'be' (like English, French, etc.) and those which do not (Russian, Hindi, etc.). ${ }^{18}$ Given this assumption, both situations might wisely be treated as resulting from syntactic transformations of a single initial structure (see Rouveret 1998 for references and a positive appraisal of this approach).

What should this structure look like? First of all, insofar as 'be' is an inherently impersonal verb, it can reasonably be assumed that as $\mathrm{V}$ head it selects a single argument in complement position. Moreover, this sole argument must surely be a small clause with a P-category head. The subject of this clause, i.e. the specifier of the PP, must be the NP expressing the thing possessed. The predicative P' constituent will then associate the NP expressing the possessor with the $\mathrm{P}$ head. The outcome should be something 
like (58).

$$
\left.\left.\ldots \text { [vp be [pp } \mathrm{NP}_{\text {possessee }}\left[\mathrm{p}, \text { at } \mathrm{NP}_{\text {possessor }}\right]\right]\right]
$$

This structure clearly displays the two possible choices for any language: if $\mathrm{P}$ is not incorporated into $\mathrm{V}$, the $\mathrm{P}$ ' constituent, i.e. $\mathrm{P}$ and the possessor it introduces, must move to the beginning of the sentence where it becomes the support for the predication at the end. This is how a possessive construction without a verb 'have' can arise:

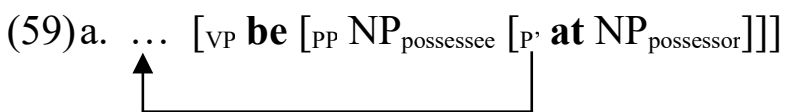

b. $\left[\mathrm{P}, \text { at } \mathrm{NP}_{\text {possessor }}\right]_{\mathrm{i}}\left[\mathrm{VP}\right.$ be $\left.\left[\mathrm{PP} \mathrm{NP}_{\text {possessee }} \mathrm{t}_{\mathrm{i}}\right]\right]$

If, on the other hand, Head Movement incorporates $\mathrm{P}$ into $\mathrm{V}$ and thus generates a transitive verb meaning 'have', the NP complement of P must become the subject of the predication which follows:

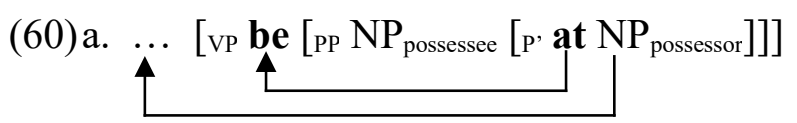

b. $\left[\mathrm{NP}_{\text {possessor }}\right]_{j}\left[\mathrm{vP}\right.$ be-at $\left.\mathbf{t}_{\mathrm{i}}\left[\mathrm{PP} \mathrm{NP}_{\text {possessee }} \mathrm{t}_{\mathrm{i}} \mathrm{t}_{\mathrm{j}}\right]\right]$

How then does this approach help to explain the apparent contradictions in the Finnish data? To answer this question, it suffices to specify to the commonplace that semantic cases must be the manifestation of $\mathrm{P}$ heads. As Nikanne (1993:77-81) has clearly shown, this notion in no way implies that semantic cases must themselves be P heads cliticized on a noun. In Finnish, the position of these morphemes in the word and the phenomenon of case agreement immediately falsify this analysis. The hypothesis which best fits the data would be that "the semantic cases are assigned by empty Ps, each of 
which correspond[s] to exactly one locative case" (ibid.).

Clearly, if this hypothesis is correct, it provides an interesting solution to the problem stated in 4.1. Historically, the Finnish possessive construction must have been a locative inversion generated as in (59). Thus, the derivation for a sentence like Pekalla on auto 'Pekka has a car' must have been as in (61) where the P' constituent moves to the beginning of the sentence after the $\mathrm{P}$ head has assigned case to the possessor NP.

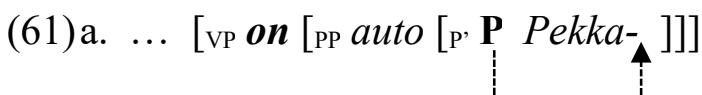

$$
\begin{aligned}
& \text { b. ... [vр } \boldsymbol{o n} \text { [рр auto [P, P Peka-lla }]]] \\
& \text { c. } \ldots[\mathrm{vp} \boldsymbol{o n}[\mathrm{pp} \text { auto }[\mathrm{p}, \mathbf{P} \text { Peka-lla }]]] \\
& \text { d. [p, P Peka-lla }]_{\mathrm{i}}\left[{ }_{\mathrm{vp}} \boldsymbol{o n}\left[{ }_{\mathrm{pp}} \text { auto } \mathrm{t}_{\mathrm{i}}\right]\right]
\end{aligned}
$$

At some point, however, this construction must have been reanalyzed by speakers without any change in the surface form of the utterance, so that a [SVO] sentence was generated as in (60). This is why Pekalla on auto 'Pekka has a car' appears today to be the outcome of the syntactic derivation in (62).

$$
\begin{aligned}
& \text { (62)a. ... [vр on [pp auto [p, P Pekka-^] ]] } \\
& \text { b. ... [vр } \left.\left.\boldsymbol{o n}\left[{ }_{\mathrm{pp}} \text { auto [p, } \mathbf{P} \text { Peka-lla }\right]\right]\right] \\
& \text { c. ... [vp on [ } \left.\left.{ }_{\mathrm{Pp}} \text { auto }[\mathrm{p}, \mathbf{P} \text { Peka-lla }]\right]\right] \\
& \text { d. } \ldots\left[\text { [vр } \boldsymbol{o n}-\mathbf{P}_{\mathrm{i}}\left[\mathrm{pp} \text { auto }\left[\mathrm{p}, \mathrm{t}_{\mathrm{i}} \text { Peka-lla }\right]\right]\right] \\
& \text { e. }\left[{ }_{\mathrm{NP}} \text { Peka-lla }\right]_{\mathrm{j}}\left[{ }_{\mathrm{vp}} \boldsymbol{o n}-\mathbf{P}_{\mathrm{i}}\left[{ }_{\mathrm{pp}} \text { auto } \mathrm{t}_{\mathrm{i}} \mathrm{t}_{\mathrm{j}}\right]\right]
\end{aligned}
$$


Here the $\mathrm{P}$ head without phonetic content is incorporated into $\mathrm{V}$ after having assigned case to the possessor NP. This operation results in a transitive verb head (which can therefore assign accusative case) with the semantic content of a verb 'have' but no change of form since the $\mathrm{P}$ head is empty. Under these circumstances, the complement of P, the possessor NP, must now move to subject position in the sentence whence it can ccommand an anaphoric constituent on the NP for the thing possessed. Its case has no meaning; it is merely the effect of the dependency relationship formed with $\mathrm{P}$ at an earlier stage of the derivation.

The value of this kind of analysis is its ability to set up a coherent framework incorporating all the morphological, syntactic, and semantic properties of the Finnish possessive construction. No component is left out. The cost lies in the use of theoretical tools, such as transformations and phonetically null categories, which may give the impression of being too ponderous. Still, this approach "saves the phenomena" just as well if not better than any other. The mere logical possibility that it might be correct should prevent some apparently immediate conclusions from being drawn, such as the assumption that case inflection progressively loses its motivation as syntax evolves.

\section{Conclusion}

Three major points have been put forward in the present paper: (1) the Finnish genitive case cannot be treated as the semantic case of possession, even in a loose sense. It has neither semantic content nor categorial representation; it merely "reflects" certain syntactic dependency relationships among constituents. It is in short a structural case. (2) As a structural case, the Finnish genitive appears in a wide variety of environments which cannot be subsumed under a common denominator. 
There are nevertheless a few contexts where apparently genitival forms are actually relics of a semantic lative-dative case which has been progressively grammaticalized into the genitive. (3) In the possessive construction, while other Uralic languages still use a semantic case with dative sense, Finnish requires a static (adessive or inessive) locative case. Although this construction is apparently a locative inversion, it can be shown to consist of a [SVO] sentence, and an explanatory hypothesis can be produced which accounts for all the data.

\section{References}

Benveniste, Emile. 1966. Problèmes de linguistique générale I. Paris: Gallimard.

Brattico, Pauli and Alina Leinonen. 2009. Case distribution and nominalization. Syntax 12: 1-31.

Comrie, Bernard. 1975. The antiergative: Finland's answer to Basque. Chicago Linguistics Society 11: 112-121.

Comrie, Bernard. 1977. Subjects and direct objects in uralic languages: a functional explanation of case-marking systems. Etudes FinnoOugriennes 12: 5-17.

Creissels, Denis. 2006. Syntaxe générale, une introduction typologique I. Paris: Hermès Lavoisier.

Hakulinen, Auli, Maria Vilkuna, Riitta Korhonen, Vesa Koivisto, Tarja Riitta Heinonen and Irja Alho. 2004. Iso suomen kieloppi. Helsinki: Suomalaisen Kirjallisuuden Seura.

Hakulinen, Lauri. 1968. Suomen kielen rakenne ja kehitys. Helsinki: Otava. Havu, Jukka and Carita Klippi. 2006. Une langue, une nation: contexte et 
corpus de codification du finnois moderne. Histoire Epistémologie Langage 28(2): 85-123.

Holmberg, Anders. 2010. The null generic subject pronoun in Finnish: a case of incorporation in T. Parametric variation: null subjects in minimalist theory, Theresa Biberauer, Anders Holmberg, Ian Roberts and Michelle Sheehan (eds.), 200-230. Cambridge: Cambridge University Press.

Huumo, Tuomas and Nobufumi Inaba. 1997. Irrallinen genetiivi ja omistusrakenteen ongelma. Virittäjä 101(1): 27-48.

Inaba, Nobufumi. 1998. Suomalais-ugrilaisten kielten omistusrakenteesta: typologinen ja geneettinen näkökulma. Kieliopillistumisesta, analogiasta ja typologiasta, Anneli Pajunen (ed.), 144-181. Helsinki: Suomalaisen Kirjallisuuden Seura.

Ikola, Osmo. 1964. Lauseopin kysymyksiä. Tutkielma nykysuomen syntaksin alalta. Helsinki: Suomalaisen Kirjallisuuden Seura.

Itkonen, Terho. 1968. Zur Frühgeschichte der lappischen und finnischen Lokalkasus. Congressus secundus internationalis fenno-ugristarum. Pars I. Acta linguistica, Martti Kahla, Alpo Räisänen and Paavo Ravila (eds.), 202-211. Helsinki: Suomalais-Ugrilainen Seura.

Itkonen, Terho. 1985. Kieliopas. Helsinki: Kirjayhtymä.

Jaakola, Minna. 2004. Suomen genetiivi. Helsinki: SKS.

Kiparsky, Paul. 2001. Structural case in Finnish. Lingua 111: 315-376.

Korhonen, Mikko. 1987. Les grammaires des langues finno-ougriennes: esquisse historique. Histoire Epistémologie Langage 9(1): 91-110.

Korhonen, Mikko. 1996. Typological and historical studies in language by Mikko Korhonen. A memorial volume published on the $60^{\text {th }}$ anniversary of his birth. Helsinki: Suomalais-Ugrilainen Seura.

Koskinen, Päivi. 1997. Features and categories. Non-finite constructions in Finnish. $\mathrm{PhD}$ dissertation, University of Toronto, Department of Linguistics. 
Laitinen, Lea and Maria Vilkuna. 1993. Case-marking in necessive construction and split intransitivity. Case and other categories in Finnish syntax, Anders Holmberg and Urpo Nikanne (eds.), 23-48. Berlin and New York: Mouton de Gruyter.

Lehmann, Christian. 1985. Grammaticalization. Synchronic variation and diachronic change. Lingua e stile 20: 303-318.

Leino, Jaakko. 2003. Antaa sen muuttua. Suomen kielen permissiivirakenne ja sen kehitys. Helsinki: Suomalaisen Kirjallisuuden Seura.

Mahieu, Marc-Antoine. 2007. Cas structuraux et dépendances syntaxiques des expressions nominales en finnois. PhD dissertation, University of Paris-7, Department of Linguistics.

Mahieu, Marc-Antoine. 2008. Les cas structuraux finnois: anti-ergativité scindée et dépendances longue distance. Etudes Finno-Ougriennes 39: 65-103.

Maling, Joan. 1993. Of nominative and accusative: the hierarchical assignment of grammatical cases in Finnish. Case and other categories in Finnish syntax, Anders Holmberg and Urpo Nikanne (eds.), 49-74. Berlin and New York: Mouton de Gruyter.

Manninen, Satu. 2003. Small phrase layers. A study of Finnish manner adverbials. Amsterdam and Philadelphia: John Benjamins.

Milsark, Gary. 1985. Case theory and the grammar of Finnish. Proceedings of New England Linguistics Society XV, Steve Berman, Jae-Woong Choe and Joyce McDonough (eds.), 319-331. Amherst: Graduate Linguistic Student Association of the University of Massachusetts.

Nelson, Diane. 1998. Grammatical case assignment in Finnish. New York: Garland.

Nikanne, Urpo. 1993. On assigning semantic cases in Finnish. Case and other categories in Finnish syntax, Anders Holmberg and Urpo. Nikanne (eds.), 75-87. Berlin and New York: Mouton de Gruyter.

Reime, Hannu. 1993. Accusative marking in Finnish. Case and other 
categories in Finnish syntax, Anders Holmberg and Urpo Nikanne (eds.), 89-109. Berlin and New York: Mouton de Gruyter.

Renault, Richard. 1991. Recherches en syntaxe du finnois: les désinences personnelles. PhD dissertation, University of Paris-8, Department of Linguistics.

Rouveret, Alain. 1998. Points de vue sur le verbe "être". "Être" et "Avoir". Syntaxe, sémantique, typologie, Alain Rouveret (ed.), 11-65. Paris: Presses Universitaires de Vincennes.

Sauvageot, Aurélien. 1973. L'élaboration de la langue finnoise. Paris: Klincksieck.

Setälä, Emil Nestor. 1898. Suomen kielioppi: äänne- ja sanaoppi. Oppikoulua ja omin päin opiskelua varten. Helsinki: Otava.

Taraldsen, Tarald. 1986. On the distribution of nominative objects in Finnish. Features and projections, Peter Muysken and Henk van Riemsdijk (eds.), 139-162. Dordrecht: Foris.

Toivainen, Jorma. 1993. The nature of the accusative case in Finnish. Case and other categories in Finnish syntax, Anders Holmberg and Urpo Nikanne (eds.), 111-128. Berlin and New York: Mouton de Gruyter.

Vainikka, Anne. 1989. Deriving syntactic representations in Finnish. Ahmerst: Graduate Linguistic Student Association of the University of Massachusetts.

Vainikka, Anne. 1993. The three structural cases in Finnish. Case and other categories in Finnish syntax, Anders Holmberg and Urpo Nikanne (eds.), 129-159. Berlin and New York: Mouton de Gruyter.

Vilkuna, Maria. 2000. Suomen lauseopin perusteet. Helsinki: Edita. 
1 Many thanks to Raymond Boyd, Eva Havu, Jukka Havu, Johanna Kuningas, Alain Rouveret, the two editors of this volume and the two anonymous reviewers for extremely helpful discussion and comments.

2 This paper focusses on official standard Finnish (yleiskieli, the "general language" of the Finnish nation). This standard form is based on the written language (kirjakieli) as developed and codified during the second half of the 19th century using features characteristic of the range of regional dialects. It differs in a number of ways from the standard spoken language (yleispuhekieli). See Sauvageot (1973); Havu and Klippi (2006).

3 It will be impossible to discuss all the issues raised by Table 1 in this paper, but closer attention will be given to a few points, particularly the status of the accusative. The genitive morpheme $-n$ has several allomorphs including -den/-tten and -en on the plural root. With the essive, partitive, inessive, elative, adessive, ablative, and abessive cases, the choice of one or the other of these allomorphs will depend on the principle of vowel harmony. For the illative, the symbol $\mathrm{V}$ stands for the closest preceding vowel. The comitative and the instructive are non-productive cases.

4 The glossing in this paper follows the Leipzig Glossing Rules, with the following additions: ABE abessive, ADE adessive, DAT.GEN dative-genitive, ELA elative, ILL illative, INE inessive, PART partitive, PRET preterit, PX possessive suffix.

5 Note that in Finnish a DP can itself be selected by a D head, as in [DP tämä [DP Pekan [AP vanha [NP auto]]]] 'this old car of Pekka's'. For further details on the prenominal genitive in Finnish, see Hakulinen et al. (2004:566-573). For a more developed theoretical discussion of the conditions on genitive case assignment in the Finnish DP, see Brattico and Leinonen (2009).

6 Another case would be the adjective pehmeä 'soft' in pumpulin pehmeä 'soft as cotton'. It is nevertheless possible to account for this case by assuming an N-A compound noun; the components are indeed often written as a single word. Regarding the distribution and semantic value of the genitive in compound nouns, see Hakulinen et al. (2004:387-421). 
7 It is interesting to note that the quantifiers paljon and vähän themselves come from a reanalysis of two former nouns in the genitive: paljo $(+\boldsymbol{n})$ 'abundance, large amount' and $v \ddot{a} h \ddot{a}(+\boldsymbol{n})$ 'small amount'. It is uncertain whether they were assigned genitive case for use as preposed noun modifiers (see $\S 2.1$ ) or, as Toivainen (1993:122-125) argues, as direct objects of verbs (see $\S 2.6)$.

8 In some cases, the adjective in -inen and its preposed genitive complement are reanalyzed as a compound: hyvännäköinen 'lovely' (< 'fine to be seen'), luonnonmukainen 'natural' (< 'matching nature'), samanikäinen 'of the same age', tietyntyyppinen 'of a certain type', etc.

9 See Manninen (2003) for a more detailed theoretical discussion of the conditions for assignment of the genitive in the Finnish PP.

10 There is no room here for even the briefest discussion of the properties of each of the many types of Finnish participial clauses. See Koskinen (1997) for a detailed theoretical approach to this question.

11 An anonymous reviewer rightly notes that the same construction is acceptable with some inergative verbs (uskon [lapsia leikkivän puistossa] 'I believe there are children playing in the park'), and even more rarely with some transitive verbs. See Itkonen (1985:64-65).

12 These are the essential facts. There are, however, complications in specific cases. (1) In interronegative sentences with injunctive import, the object may not take the partitive: eikö oteta lepohetki? 'let's take a break!' (< 'don't we take a break?'). (2) A small number of atelic verbs (e.g., omistaa 'own', sisältää 'contain', nähdä 'see', tietää 'know', muistaa 'remember'), often called "quasi-resultatives", do not assign the partitive to their objects: omistan talon 'I own a house'. Conversely, some momentarily telic verbs govern the partitive unless they express the attainment of a resulting state: ammuin lintua 'I shot at the bird' (vs. ammuin linnun 'I shot the bird dead'). (3) Sometimes in dialogue, if it is clear from the context that a (telic) process is to be viewed as perfective, the partitive can be 
used, and is even more natural, on the object: - kirjoitin sen kirjeen 'I wrote that letter'; kuinka kauan kirjoitit sitä? 'how long did it take you to write it?'; - kirjoitin sitä pari tuntia 'I wrote it in a couple of hours'. I thank Jukka Havu and one of the anonymous reviewers for calling my attention to the latter point.

13 See Holmberg (2010) for a theoretical discussion of the issues raised by the syntax of generic sentences.

14 In some varieties of Finnish (child language, eastern dialects), this animacy split would seem also to include given names and the nouns designating immediate kin. In Estonian, it affects only the first and second person pronouns (Mahieu 2008:76-82).

15 In this sentence, the partitive indicates non-attainment of the telos rather than the atelic nature of the VP as in (44a). If the telos had been attained, the object would have been in the genitive, and the modifier would have shifted to the inessive: Pekka luki kirjan tunnissa 'Pekka read the (whole) book in an hour'.

16 See Nikanne (1993:86): “According to the distribution, binding, and predication facts, the locative and other semantic cases seem to form PPs where the NP in the locative cases is embedded by some head. Because we are dealing with PPs, the head is probably a P." It must be stressed that the notion that semantic cases are the manifestation of $\mathrm{P}$ heads in no way implies that these cases are themselves Ps cliticized on nouns (see $\S 4.2$ ).

17 In a transformational approach, the inherently impersonal nature of the verb olla 'be' would suggest that the NP expressing the thing possessed is not directly generated as subject of the sentence but rather as subject of the small clause selected by the verb olla, i.e. as specifier of the $\mathrm{P}$ head. The deep structure of (49a) would then be [VP on $[\mathrm{PP}$ auto $[\mathrm{P}, \mathrm{P}$ Pekan]]].

18 “'Have' is just 'be-at' turned around” (Benveniste 1966:199). 